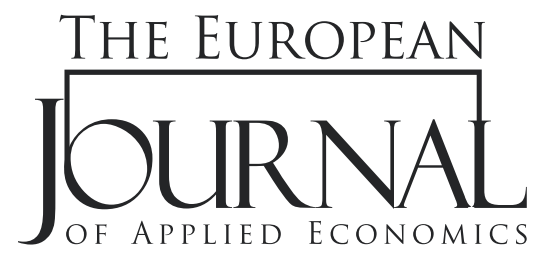

\title{
A SIMULTANEOUS EQUATION MODEL OF GLOBALIZATION, CORRUPTION, DEMOCRACY, HUMAN DEVELOPMENT AND SOCIAL PROGRESS
}

\author{
Sudhanshu K. Mishra \\ North-Eastern Hill University, \\ India
}

\begin{abstract}
:
This study builds a simultaneous equation model that establishes interconnections among the measures of globalization, measures of democracy, human development, corruption perception index and per capita income, which in turn jointly influence social progress. The model has eleven equations in which the response variables and the predictor variables are log-linearly related. The empirical data used for estimation of the model pertain to the period 2006-2016 for 116 countries distributed over all the continents. The model has been estimated by the conventional Two-Stage Least Squares (2-SLS) and alternatively by a modified 2-SLS in which, at the second stage, Shapley value regression has been used to ameliorate the detrimental effects of collinearity among the predictor variables. The modified 2-SLS outperforms the conventional 2-SLS. The study finds that globalization positively influences and is influenced by democracy, human development and social capital. Globalization reduces corrupt practices and integrity promotes globalization. Democracy, social capital, human development and globalization affect social progress positively. It has also been found that trans-border personal connection, cultural proximity, democracy and social capital are elastic with respect to their predictors.
\end{abstract}

\section{Article info:}

Received: February 1, 2018

Correction: February 7, 2018

Accepted: February 7, 2018

\section{Keywords:}

Globalization,

democracy, social progress, simultaneous equation model, Shapley value regression.

\section{INTRODUCTION}

This study investigates into the debated inter-relationships among globalization, political regimes, corruption, human development and social progress in a simultaneous model framework. It recognizes that a school of scholars holds that globalization and democracy uphold each other and they jointly hold back corruption, endorse human development and finally promote social progress. Globalization also positively responds to democratic practices, human development and strong social capital.

This article has been prepublished online. The prepublished version of the article can be accessed through the following link: https://mpra.ub.uni-muenchen.de/84213/ 
Nevertheless, it is acknowledged that the opponent school of scholars relate globalization to limiting the scope of democracy, promoting corruption, misaligning human and non-human capital with globalization sponsored development and consequently thwarting social progress. In what follows, an attempt has been made to put together the views and most important empirical findings of various scholars and drawing upon the same build as well as estimate a simultaneous equation model that may reveal the structural relationships among the said variables.

\section{A LITERATURE SURVEY ON RELATIONSHIPS AMONG GLOBALIZATION WITH OTHER SOCIO-ECONOMIC VARIABLES}

In this section we put together the views and empirical findings of various scholars on the relationship between globalization, political regime, human capital, social capital and social progress as visualized by Stiglitz et al. (2009) and Social Progress Imperative. Human capital is summarily measured by the human development index and corruption perception index has been used as a prototype measure of social capital.

\section{Relationship between Globalization and Political Regime}

Numerous studies have been carried out to investigate into the relationship between regime type (democracy to authoritarian) and globalization with the causal arrow indicating towards either direction. A good number of studies investigate into the relationship between regime type and development (Przeworski and Limongi, 1993) that cluster around the Lee thesis and in view of globalization being considered as a means to development have a discernible bearing on the relationship between regime type and globalization. Among such studies, Huntington and Jorge (1975), Marsh (1979), Weede (1983), Landau (1986), Kohli (1986) and Helliwell (1992) provide empirical evidences that indicate negative to inconsequential impact of democracy (or positive to insignificant impact of authoritarianism) on development. On the contrary, Dick (1974), Kormendi and Meguire (1985), Pourgerami (1988, 1991), Scully (1988; 1992), Barro (1989), Remmer (1990), Leblang (1997), Halperin et al. (2005) and Knutsen (2008a; 2008b; 2010) provide empirical evidences of a favourable impact of democracy (or unfavourable impact of authoritarianism) on development. A number of studies assert that there is no direct relationship between regime type and development. There are intermediate factors such as the (already) attained development level (Przeworski, 1966; Adelman and Morris, 1967), type (whether bureaucratic or traditional) of authoritarian regime (Sloan and Tedin, 1987), attributes and inclination of the authoritarian ruler (Barro, 1997), regional factors with the historical, institutional, cultural and geographic specificities that vary over the continents (Grier and Tullock, 1989), degree of entrenchment of the political elite class and political competition that they face (Acemoglu and Robinson, 2006a), etc that modify the relationship between regime type and development and, therefore, one cannot relate them unconditionally. A number of empirical studies establish connection between the regime type and the factors determining development. Boix (2003) and Knutsen (2007) found a positive impact of democracy on rule of law and consequentially the protection of property rights. Knutsen (2008b) and Hegre and Fjelde (2008) found that democratic governments perform better on control of corruption. Rodrik (1998) found that democracy helps increase real wages of workers leading to increase in consumption, which may have efficiency-promoting effects leading to development (Myrdal ,1972: p. 54). Sen (1999) stresses on freedom and social progress, rather than economic development, and favours democracy for that reason. 
A number of studies assess the impact of trade and development on the regime type. Schumpeter (1950), Lipset (1959) and Hayek (1960) hold that free trade and capital flows foster demands for democracy via (and also in favour of) enhancement of the efficiency of resource allocation and consequent economic development. Eichengreen and Lebang (2006) find a bi-directional causality that mutually re-enforce democracy and globalization. Kollias and Paleologou (2016) find a positive impact of globalization on democracy, although it is not true for the countries of all income groups. Globalization hardly promotes democracy in poor economies. Acemoglu and Robinson (2006b) shows that key democratizing forces associated with trade openness depend on country's relative factor endowment. Rudra (2005) observes that economic globalization leads to improvements in democracy only if safety nets are used simultaneously as a strategy for providing stability and building political support. Milner and Mukherjee (2009) find that democracy fosters trade and capital account liberalization, but not all the aspects of globalization. Li and Reuveny (2003) find that different constituents of globalization affect democracy in different manner not conformal to each other. Haffoudhi and Bellakhal (2016) find that the efforts of globalization in poor countries suffering from famines, chronic under-nutrition, poor state of human development, low efficiency and poor state of resource allocation would not promote democracy.

There are a number of studies that point out undesirable effects of globalization on the political sphere of less developed countries. Schwartzman (1998) observes that globalization and democracy reinforce each other to facilitate the fulfilment of the interest of the dominant world economic system. Sobhan (2003) observes that the countries with weak democratic institutions and undiversified or externally dependent economies are often exploited. Turyahikayo (2014) observes that globalization has been used as a tool by the established democracies/economies for exploitation of cheap labour and dumping the industrial waste in poor countries. Steiner (2015) observes that globalization may have a negative effect on public participation in the political domain.

Stein (2016) opines that a sovereign state system, democratic governments, and an integrated global marketplace cannot coexist. It is most likely therefore that globalization will affect the sovereignty of less developed countries adversely.

\section{Relationship between Globalization and Non-Material Capital}

Scholars are divided on the relationship of globalization with human development. Sirageldin (2002) recognises the complex character of human development which is an outcome of the historical process of symbolic cultural evolution. Globalization may interfere with the social process. The Human Development Report 1999 took note of the adverse consequences of unregulated globalization on human development and recommended stronger global governance (Naqvi, 2002). Rabbanee et al. (2010) observe that while globalisation has often gone along with privatization and reduction of government help to the poor, it affects human development adversely. Huynen et al. (2005) analyse various pathways in which globalization may affect public health and highlights the need to regulate the impacts of globalization. Ball (2005) observes that globalization romanticizes 'the private' and demonizes the public welfare provision for the poor. Yang (2006) laments the pervasive ill effects of privatization of education in China. Globalization has affected the education sector to turn against the poor. As Lake and Baum (2001) point out, democracy is often instrumental in looking into the interest of the weaker section through public provisioning. Globalization may affect government aided public provisioning and affect social welfare, especially of the deprived class, adversely. Diametrically opposite to this, Tsai 
(2006) finds that globalization affects human development/welfare positively. Sapkota (2011) studies a large number of countries and finds that all components of globalization (economic, social and political) have positive and statistically significant effect on human development.

There are many research studies that observe the impact of globalization on human development conditional or partial. For Sabi (2007) impact of globalization on human development is not appreciable in developing countries at low or low-middle income groups. Figueroa (2014) finds that in Central and South American countries overall globalization as well as social and political components of it has positive effect, but economic globalization has a negative effect on human development. Asongu (2012) studies African countries and finds that while trade globalization improves human development, financial globalization has the opposite effect. Lee and Vivarelli (2006) hold that levels of economic and human development are crucially important to determine the direction and the scope to globalization forces.

Along with the human capital, the social capital (Durkheim, 1997; Hanifan, 1916) is crucially important for development. Social capital not only generates internal economies, it also attracts material capital from abroad and helps in globalization. It is well acknowledged that corruption and malpractices erode away social capital and discourage inflow of foreign capital while a strong legal framework to check corruption enhances the inflow of foreign capital (Bayer and Alakbarov, 2016).

Knutsen (2008b) and Hegre and Fjelde (2008) found that democratic governments perform better on control of corruption. This control may support globalization. Lalountas et al. (2011) observe that globalization is a powerful weapon against corruption only for middle and high income countries, while for low income countries globalization has no significant impact on corruption. Das and DiRienzo (2009) find a nonlinear relationship between globalization and corruption. The effect of globalization on corruption is dependent on the level of globalization. The highest corruption levels are realized at moderate or transitioning levels of globalization.

Globalization has brought government officials and international businesses and trade agents into a close relationship and consequentially increased the opportunities for rent-seeking. Eisner (1995), Gould (1991) and Jreisat (1997) argue, therefore, that globalization has increased the opportunity of the use of official position for personal gain. Globalization has also made the detection of corrupt practices more difficult (Leiken, 1997; Elliott, 1997). Ewoh et al. (2013) find that while globalization of assets and capital markets has promoted corruption worldwide, it affects developing nations negatively more than it impacts advanced countries. On the contrary, Ades and Di Tella $(1997 ; 1999)$, Brunetti and Weder (2003), Treisman (2000) and Herzfeld and Weiss (2003) find that globalization leads to reduction in corruption mainly due to openness. Badinger and Nin (2014) find that globalisation (trade and financial openness) has a negative effect on corruption, which is more pronounced in developing countries, while inequalities increase corruption. Golden (2002) found that in Italy globalization led to decrease in corruption levels.

\section{Relationship between Globalization and Social Progress}

Globalization necessarily favours a market-based economy because it means economic integration of economies through markets. However, market that caters to the private interest may go against the public interest (Keynes, 1926; Hirsch, 1977; Naqvi, 2002). Singer (1950), Streeten (1998) and Naqvi (2002) argue that globalization may distort structural transformation, induce social tension, aggravate inequalities and erode the social-support systems as well as the established identities and values. Stiglitz et al. (2009) have pointed out that globalization is market-based and only poorly integrated with 
the non-market based social processes, consequently contributing to the weakening of a sense of community. On the contrary, empirically, it has been found that the social progress index responds positively to globalization index (Mishra, 2017).

From the literature cited above, it is understandable that there is no direct relationship among globalization, political regimes, corruption, human development and social progress; they are related with each other through a complex network of institutions, historical precedents, resource endowments, socio-economic class structure and a host of other country-specific attributes. However, when such relationships are investigated for a large number of countries together, the country-specific attributes may be cancelled out to a large extents and some clear pattern might be discernible. The present investigation begins with such an optimistic presupposition.

\section{A SIMULTANEOUS EQUATION MODEL OF GLOBALIZATION, NON-MATERIAL CAPITAL, REGIME TYPE AND SOCIAL PROGRESS}

In the light of the literature cited above as well as the reasoning that guides an empirical research in economics, the present study hypothesizes a bi-directional causal relationship between the two sets of variables; the first set incorporating the measures of economic, social and political globalization and the second set consisting of the measures of political regime type and the measures of non-material capital (human development as a measure of human capital and corruption perception as a measure of social capital). Additionally, the measures of globalization and the measures of non-material capital are directly or indirectly influenced by the economic prosperity of a country (represented by per capita income). Finally, it is visualized that social progress is influenced by globalization, non-material capital, political regime type as well as economic development.

\begin{tabular}{|c|c|}
\hline $\begin{array}{l}\text { Block-2 } \\
\text { Three Aspects of Globalization }\end{array}$ & $\begin{array}{l}\text { Block-1 } \\
\text { Economic Development (Per Capita Income) }\end{array}$ \\
\hline Economic, Social, Political. & \\
\hline Six measures (in all) & Block-3: \\
\hline Economic - E1 and E2 & Non-material Capital (Human, HD and Social, CP); \\
\hline Social - S1, S2 and S3 & Socially Responsive Political System (Democracy \\
\hline Political - P & Index, DI) \\
\hline Composite Globalization & \\
\hline Index - GI & Block-4 \\
\hline & Social Welfare (Social Progress, SP) \\
\hline
\end{tabular}

Chart-1. Schematic Flow Diagram of the Model

The schematic flow diagram of the model (which extends the abridged model in Mishra, 2018) is presented in Chart-1. It is a system of eleven structural equations (Chart-2) of which the first ten make three stimulator and/or moderator blocks while the last equation makes the fourth or final impact or response block. The first three blocks formulate how the different aspects of globalization are self-concordant and how they are influenced by non-material capital, political organization and per capita income of a nation. Per capita income is a stimulant to globalization. Globalization and the measures in the third block are mediator or moderators. They conceptualize how different aspects of 
globalization influence as well as are influenced by non-material capital and political organization. The fourth block formulates how globalization, non-material capital, political regime and economic development influence the overall social welfare or social progress of a nation.

The eleven structural equations of the model are presented below. Functional form-wise, it is visualized that the relationships among the variables are linear in logarithm or $\log (y)=\log \left(\alpha_{0}\right)+\sum^{m} \alpha_{j} \log \left(x_{j}\right)$ , where $y$ is a response variable, $x_{j}$ is a stimulus, predictor or explanatory variable, $\alpha_{0}$ is a constant and $\alpha_{j}$ is the coefficient (which may also be interpreted as a measure of elasticity of $y$ with respect to $x_{j}$ ).

$$
\begin{array}{lr}
E 1_{t}=f\left(E 2_{t}, S 1_{t}, P C L_{06}, C P_{06}, H D_{06}, P C Y_{06}\right) & \text { eq. }(01) \\
E 2_{t}=f\left(S 2_{t}, S 3_{t}, P t, E P P_{06}, P P N_{06}, C P_{06}, H D_{06}\right) & \text { eq. }(02) \\
S 1_{t}=f\left(E 1_{t}, S 3_{t}, F O G_{06}, P C L_{06}, C V L_{06}, C P_{06}, H D_{06}\right) & \text { eq. }(03) \\
S 2_{t}=f\left(E 2_{t}, P P N_{06}, P C L_{06}, C V L_{06}, H D_{06}, P C Y_{06}\right) & \text { eq. }(04) \\
S 3_{t}=f\left(P_{t}, P C L_{06}, C P_{06}, H D_{06}\right) & \text { eq. }(05) \\
P_{t}=f\left(E 1_{t}, E 2_{t}, S 1_{t}, S 2_{t}, S 3_{t}, P C Y_{06}\right) & \text { eq. }(06) \\
D I_{16}=f\left(E 2_{t}, S 1_{t}, S 2_{t}, S 3_{t}, P_{t}\right) & \text { eq. }(07) \\
C P_{16}=f\left(E 1_{t}, E 2_{t}, S 1_{t}, S 2_{t}, S 3_{t}, P_{t}\right) & \text { eq. }(08) \\
H D_{15}=f\left(E 1_{t}, S 2_{t}, S 3_{t}\right) & \text { eq. }(09) \\
G I_{10}=f\left(C P_{06}, H D_{06}, P C Y_{06}, D I_{06}\right) & \text { eq. }(10) \\
S P_{16}=f\left(D I_{16}, C P_{16}, H D_{15}, G I_{10}, P C Y_{06}\right) & \text { eq. }(11)
\end{array}
$$

\begin{tabular}{|c|c|c|c|}
\hline Sl. No. & Symbol & $\begin{array}{l}\text { Socio-Economic and } \\
\text { political Aspects }\end{array}$ & Description \\
\hline 1 & E1 & $\begin{array}{l}\text { Economic Globalization } \\
\text { Max or Min (2006-14) }\end{array}$ & $\begin{array}{l}\text { Actual economic flows such as trans-border trade, direct } \\
\text { investment and portfolio investment. }\end{array}$ \\
\hline 2 & E2 & $\begin{array}{l}\text { Economic Globalization } \\
\text { Max or Min (2006-14) }\end{array}$ & $\begin{array}{l}\text { Relaxation of restrictions on trans-border trade as well as } \\
\text { capital movement by means of taxation, tariff, etc. }\end{array}$ \\
\hline 3 & S1 & $\begin{array}{l}\text { Social Globalization } \\
\text { Max or Min }(2006-14)\end{array}$ & $\begin{array}{l}\text { Trans-border personal contacts such as degree of tourism, } \\
\text { telecom traffic, postal interactions, etc. }\end{array}$ \\
\hline 4 & S2 & $\begin{array}{l}\text { Social Globalization } \\
\text { Max or Min (2006-14) }\end{array}$ & Flow of information. \\
\hline
\end{tabular}

\section{Chart-2. Functional Structure of the Model}

The lists of endogenous and predetermined/exogenous variables of the model are presented in Chart 3 and Chart- 4 . 


\begin{tabular}{cccl}
5 & S3 & $\begin{array}{c}\text { Social Globalization } \\
\text { Max or Min (2006-14) }\end{array}$ & Cultural proximity. \\
6 & P & $\begin{array}{c}\text { Political Globalization } \\
\text { Max or Min (2006-14) }\end{array}$ & Trans-national political set up. \\
7 & DI16 & Political Regime & Democracy Index for 2016. \\
8 & CP16 & Social Capital & Corruption Perception index for 2016. \\
9 & HD15 & Human Development & Human Development Index for 2015. \\
10 & GI10 & Overall Globalization & Max (2006-2014) or Min (2006-2014) \\
11 & SP16 & Social Progress & Social Progress Index for 2016. \\
\hline
\end{tabular}

Chart-3. List of Endogenous Variables

\begin{tabular}{ccll}
\hline Sl. No. & Symbol & Socio-Economic and political Aspects & \multicolumn{1}{c}{ Description } \\
1 & EPP06 & Measure of Democratic Practices & Electoral Process and Pluralism for 2006. \\
2 & FOG06 & Measure of Democratic Practices & Functioning of Government for 2006. \\
3 & PPN06 & Measure of Democratic Practices & Political Participation for 2006. \\
4 & PCL06 & Measure of Democratic Practices & Political Culture for 2006. \\
5 & CVL06 & Measure of Democratic Practices & Civil Liberties for 2006. \\
6 & CP06 & Social Capital & Corruption Perception index for 2006. \\
7 & HD06 & Human Development & Human Development Index for 2005. \\
8 & PCY06 & Per Capita Income & Per capita Income (in Int $\$ 1000)$ for 2006 \\
9 & DI06 & Overall Measure of Democracy & Overall Democracy Index for 2006 \\
\hline
\end{tabular}

Chart-4. List of Exogenous/Predetermined Variables

\section{DATA OR THE MEASURES USED IN THIS STUDY}

This study covers 116 countries drawn from all the continents including Africa (38 countries), the Americas (23 countries), Asia (26 countries), Europe ( 26 countries) and Oceania ( 3 countries). These countries together represent all types of political regime (full democracy to authoritarian), all levels of globalization (very low, to very high) and all levels of economic development, social progress, human capital and social capital. The data used by us are presented in the appendix. Table-A-1 present five measures for democracy $\left(\mathrm{EPP}_{\mathrm{i} 06}, \mathrm{FOG}_{\mathrm{i} 06}, \mathrm{PPN}_{\mathrm{i} 06}, \mathrm{PCL}_{\mathrm{i} 06}, \mathrm{CVL}_{\mathrm{i} 06}\right.$ and $\mathrm{DI}_{00} ; \mathrm{i}=1$ through 116) for the year 2006 as well as the overall measure of democracy DI ${ }_{16}$ for 2016. Table-A.2 presents corruption perception Index, human development Index and also the overall democracy index for 2006 and 2016. Table-A-2 also contains Social Progress Index (2016), Per Capita Income (2015 - in Int\$1000) and overall Globalization Indices scenario-wise (GI ${ }^{\max }$ and GI ${ }^{\min }$, explained below). Table-A-3 and Table-A-4 present aspect-wise sub-indices as well as overall globalization indices for the two alternative (optimistic and pessimistic) scenarios explained below. 


\section{Measures of Different Aspects of Globalization with Two Scenarios}

As it has been pointed out earlier, $\mathrm{KOF}(2017)$ visualizes and constructs three complementary aspects of globalization, economic, social and political, which are merged together by using the Principal Component Analysis to provide the overall index of globalization (Dreher, 2006; Dreher et al., 2008). This study uses those KOF sub-indices for the period 2006-2014 (KOF, 2017), but not the KOF measure of overall globalization. Instead, it uses AEMC overall index (Mishra, 2016b) of globalization based on the principle of 'almost equi-marginal contribution' that derives weights differently. Yet, the KOF and AEMC indices of overall globalization are highly correlated ( $r=0.98)$. The AEMC index, denote by $G$, is for 9 years (2006-2014) and 116 countries, i.e. $G_{i, j} ; i=1,2, \ldots, 116 ; j=2006,2007, \ldots, 2014$.

The indices of globalization of different countries fluctuate over the years on account of interactions among domestic (country-specific) and international politico-economic forces. Yet, during the study years the fluctuations are within a range. The country-specific ranges are wide or narrow depending on a particular country's domestic socio-political conditions and the overall acceptance of the globalization policy. Since the objective of this study is to gauge into the overall incidence and effects of globalization (and not into the temporal fluctuations) it is visualized that the range limits would provide better measures than the temporal variations. These limits are given by the maximum and the minimum values taken on by the globalization measures. Correspondingly, two scenarios have been visualized; the one that relates to the lower value (pessimistic scenario) and the other that relates to the upper value (optimistic scenario) of the AEMC globalization index of the country concerned. For every $\mathrm{G}_{i j}$ there are the associated sub-indices $\left[\mathrm{E} 1_{i j}, \mathrm{E} 2_{i j}, \mathrm{~S} 1_{i j}, \mathrm{~S} 2_{i j}, \mathrm{~S} 3_{i j}\right.$ and $\left.\mathrm{P}_{i j}\right] ; \mathrm{j}=2006$ through 2014 and $\mathrm{i}=1,2, \ldots, 116$. A pessimistic scenario vector is formed by:

$$
\left[E 1_{i}^{\text {min }}, E 2_{i}^{\text {min }}, S 1_{i}^{\text {min }}, S 2_{i}^{\text {min }}, S 3_{i}^{\text {min }}, P_{i}^{\text {min }}\right]
$$

which is associated with

$$
G_{i}^{\min }=\min _{\mathrm{j}}\left(\mathrm{G}_{\mathrm{ij}} ;_{\mathrm{j} \in[2006,2014]}\right), \quad \text { where } \mathrm{i}=1,2, \ldots, 116
$$

that gives the set of values associated with the lowest extent of globalization experienced by any country during 2006-2014.

Similarly, the optimistic scenario vector is:

$$
\left[E 1_{i}^{\max }, E 2_{i}^{\max }, S 1_{i}^{\max }, S 2_{i}^{\max }, S 3_{i}^{\max }, P_{i}^{\max }\right]
$$

associated with

$$
G_{i}^{\max }=\max _{\mathrm{j}}\left(\mathrm{G}_{\mathrm{ij}} ;_{\mathrm{j} \in[2006,2014]}\right), \quad \text { where } \mathrm{i}=1,2, \ldots, 116
$$

that gives the set of values associated with the highest extent of globalization experienced by any country during 2006-2014. 
We have these two scenario vectors of globalization as our endogenous variables (along with other endogenous variables) for estimation of our model. These scenarios influence and are also influenced by other variables such as the measures of democracy, human and social capital, the social progress, etc.

\section{The Measures of Non-Material Capital, democracy, economic development and social Progress}

This study uses the human development index as a comprehensive measure of human capital. The corruption perception index is uses as a prototype measure of social capital.

The Economist Intelligence Unit (EIU) of the Economist Group has published the Democracy Index for 2006 onwards for several years, including 2016. The index is based on 60 indicators grouped in five different categories namely, Electoral process and pluralism (EPP), Functioning of government (FOG), Political participation (PPN), Political culture (PCL) and Civil liberties (CVL), and a linear aggregation of indicators under each category provides a sub-index of democracy in that category or aspect. Subsequently, these five sub-indices of different aspects of democracy are linearly aggregated to yield an overall index (DI or the Index of Democracy). On the basis of the overall score value of DI the political systems of different countries may be classified into full democracies, flawed democracies, hybrid regimes and authoritarian regimes. The present study uses the aspect-wise sub-indices for 2006 and the overall indices of democracy (DI) for 2006 and 2016.

Per capita income is a standard measure of potentialities to save and invest, productivity, the level of economic activities as well as the purchasing power of a country and, therefore, by implication, the proclivities to globalization. This study uses per capita income as a promoter of globalization. Yet, per capita income may not be a good measure social welfare. In view of this, the social progress index constructed by Social Progress Imperative may be a better measure. In the present study per capita income has been considered as an input variable while the social progress index has been considered as an output variable.

\section{METHODOLOGICAL ASPECTS OF ESTIMATION OF THE MODEL}

To estimate the parameters (of the structural equations) of the model this study uses Two-Stage Least Squares (2-SLS) method, which may be considered as instrumental variable method of estimation (Reiersøl, 1945). The 2-SLS uses the Least Squares methods to estimate reduced form as well as structural parameters. However, the very procedure adopted by the 2-SLS - that at the second stage it uses the linear function of all exogenous variables together with some exogenous variables (explicitly) as predictors - renders it susceptible to collinearity, which may have deleterious effects on the standard errors of the estimated parameters, including sign reversal (Smith and Brainard, 1976). To ameliorate the obnoxious effects of collinearity, this study uses the Shapley value regression (Lipovetsky, 2006; Mishra, 2016a) at the second stage of the 2-SLS. Optimization has been done by the Differential Evolution method of global optimization (Storn and Price, 1997). 


\section{FINDINGS}

In what follows, the main findings of estimation of the model using the conventional as well as Shapley value based 2-SLS are presented for both alternative scenarios of globalization. As mentioned earlier, the use of Shapley value regression to estimate the parameters of the model is motivated by the presence of strong collinearity among the predictor variables that may not only render the coefficients estimated by conventional 2-SLS statistically insignificant, they also may bear incorrect sign. The findings presented in the next section corroborate to this concern.

The relative performance of Shapley-value based 2-SLS vis-à-vis the conventional 2-SLS in explaining different endogenous (response) variables also is important. To this end, the correlation matrices, presented in appendix Table-A-7 (pessimistic globalization scenario) and Table-A-8 (optimistic globalization scenario), are helpful. The correlation coefficients are: $r_{i j}=r\left(y_{i}, \widehat{y}_{j}\right)$, where $y_{i}$ is the $i^{\text {th }}$ observed endogenous variable and $\widehat{y}_{j}$ is the $j^{\text {th }}$ endogenous variable estimated by conventional 2-SLS. It may be noted that $r_{i, i}^{2}=r^{2}\left(y_{i}, \hat{y}_{i}\right)$ is the usual $R^{2}$ or the coefficient of determination that one reports in the regression results. Similarly, $r_{i j}=r\left(y_{i}, \breve{y}_{j}\right)$, where $y_{i}$ is the $i^{\text {th }}$ observed endogenous variable and $\breve{y}_{j}$ is the $j^{\text {th }}$ endogenous variable estimated by Shapley value regression based 2-SLS. The coefficient of correlation between conventional 2-SLS estimated endogenous variable and Shapley value regression based 2-SLS is $r_{i j}=r\left(\hat{y}_{i}, \breve{y}_{j}\right)$. A large value of $r\left(\widehat{y}_{i}, \breve{y}_{i}\right)$ indicates that the correlation between the conventional 2-SLS predicted and Shapley value regression based 2-SLS predicted vectors (of the same endogenous variable) is large or, in other words, the conventional 2-SLS and Shapley value regression based 2-SLS are highly conformal. Throughout it may be seen that $r_{i i}=r\left(\widehat{y}_{i}, \breve{y}_{i}\right)$ is large for all endogenous variables (Panel-3). Further, $r\left(y_{i}, \widehat{y}_{i}\right)$ and $r\left(y_{i}, \breve{y}_{i}\right)$ are very close to each other for all endogenous variables, although the latter is somewhat smaller than the former. This is the cost that one must pay to circumvent the deleterious effects of collinearity. These results confirm that Shapley value regression based 2-SLS will not mislead us.

\section{Estimated Structural Equations for the Pessimistic Scenario of Globalization}

The reduced form coefficients for the pessimistic scenario of globalization are presented in appendix Table-A-5. Therefore, only the estimated structural equations are presented here. Figures in the $2^{\text {nd }}$ row are standard error of estimates. 
Structural Equation Coefficients based on Conventional 2-SLS

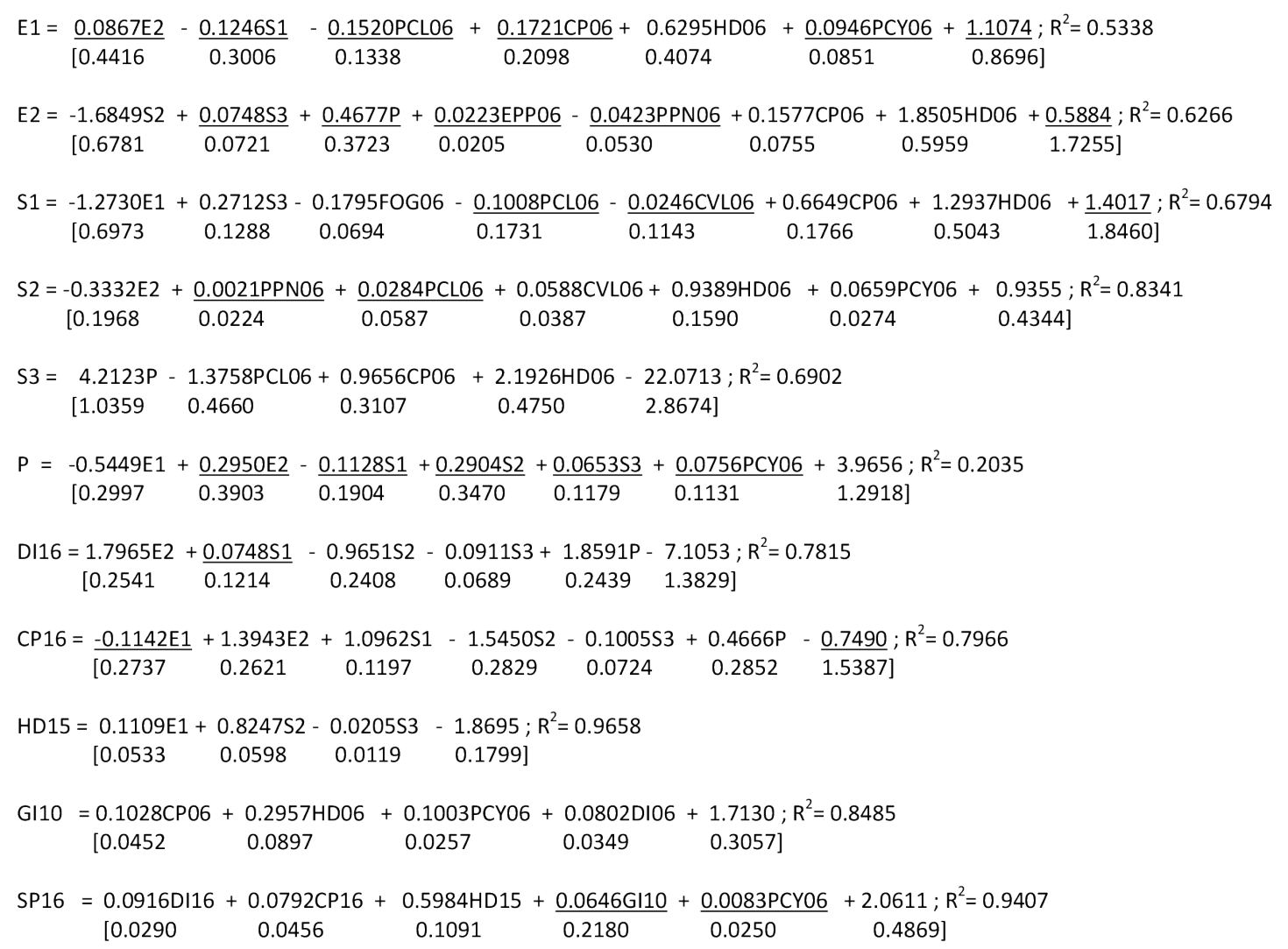

It is observed that in explaining E1 (Actual economic flows such as trans-border trade, direct investment and portfolio investment) most of the predictor variables bear statistically insignificant coefficients. The coefficients that are not statistically different from zero even at $10 \%$ level of significance have been underlined. Only HD06 (human development index) has the coefficient significantly different from zero at $10 \%$ significance. Relaxation of restrictions on trans-border trade as well as capital movement by means of taxation, tariff, etc (E2) has a negative coefficient (significant at 5\%) associated with S2 (flow of information) which is not expected. Similarly, effects of trans-border trade, flow of finance etc (E1) and functioning of the government (FOG) affect S1 (trans-border personal contacts) adversely, which is contrary to expectation. Flow of information (S2) is adversely affected by relaxation of restrictions on trans-border trade and capital movement (E2), cultural proximity (S3) is adversely affected by political culture (PCL), political aspect of globalization $(\mathrm{P})$ is adversely influenced by trans-border flow of goods, services and capital (E1) and so on which are contrary to expectation. In short, the conventional 2-SLS gives the results that are unexpected or contrary to expectation.

However, the structural coefficients associated with all predictor variables estimated by the Shapley value based 2-SLS (presented below) are positive as expected and except for a few (viz. FOG in predicting S1 and PPN in predicting S2) all others are significant at $5 \%$ or less ( $1 \%$ or even $0.1 \%)$. None of the coefficients is statistically insignificant (beyond $10 \%$ level of significance). It may be noted that there is no straightforward method to obtain standard error of estimates of the structural coefficients estimated by the Shapley value regression, and hence the Student's t values as well, which may be used for 
testing the maintained hypothesis. This study, therefore, obtains the standard error of estimates of the Shapley value based structural parameters by jackknife resampling (presented in row 2 for every equation) and the associated $t$ values (row 3 for every equation) are based on those standard error of estimates.

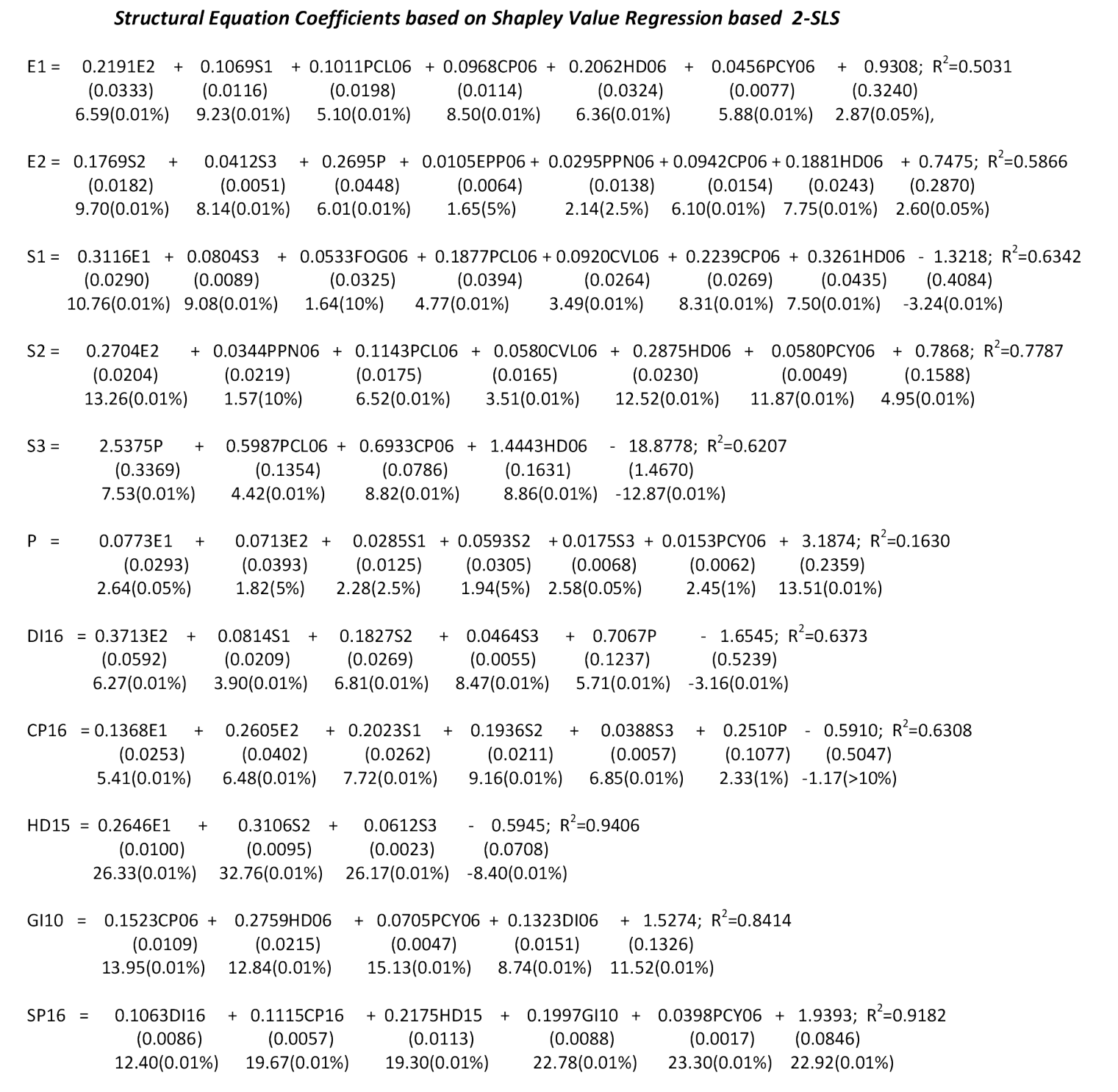

\section{Estimated Structural Equations for the Optimistic Scenario of Globalization}

The reduced form coefficients for the optimistic scenario of globalization are presented in appendix Table-A-6. Here the estimated structural equation coefficients only are presented. 


\section{Structural Equation Coefficients based on Conventional 2-SLS}

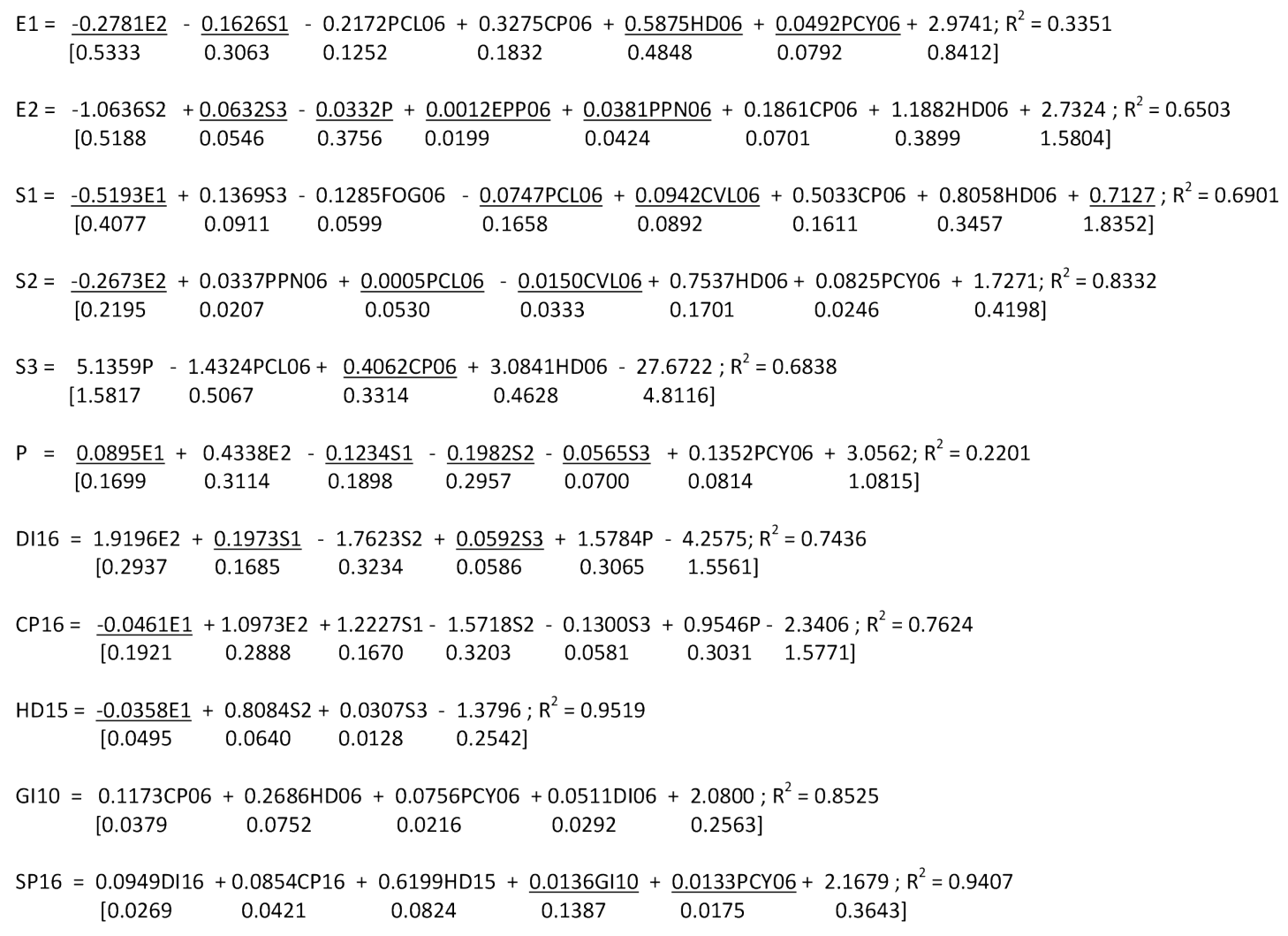

The highlights of the findings based on the structural coefficients estimated by the conventional 2-SLS are: (i) political culture (PCL) affects E1 (trans-border trade and flow of capital) adversely; (ii) flow of information (s2) affects relaxation of restriction on flow of trans-border trade, capital, etc adversely; (iii) functioning of the government (FOG) affects trans-border personal contacts (S1) adversely; (iv) political culture (PCL) affects cultural proximity (S3) adversely; (v) trans-border flow of information (S2) affects democracy adversely (DI) and (vi) trans-border flow of information (S2) and cultural proximity (S3) affect corruption perception (CP) adversely. These findings are contrary to what one may expect and hence misguiding.

However, as in the case of the pessimistic scenario noted earlier, the structural coefficients associated with all predictor variables estimated by the Shapley value based 2-SLS (presented below) are positive as expected and except one (EPP in predicting E2); all others are statistically significant at 5\% (or less) level of significance. None of the structural coefficients is statistically insignificant (beyond 10\% level of significance). As mentioned before, the standard error of estimates for the estimated structural parameters obtained by Shapley value regression have been worked out by jackknife resampling and the associated $t$ values are based on those standard error of estimates. 


\section{Structural Equation Coefficients based on Shapley Value Regression based 2-SLS}

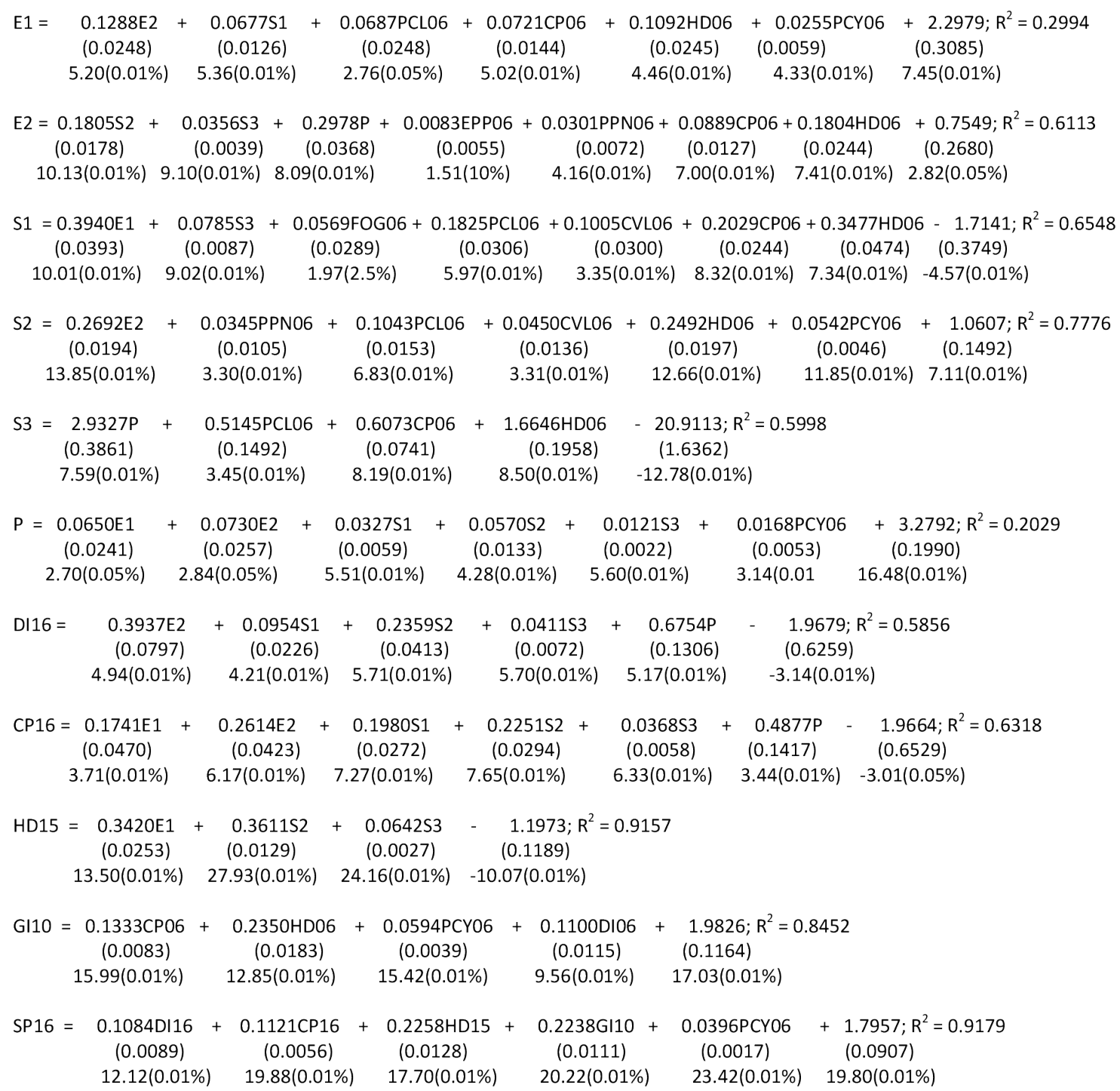

\section{The Sum of Elasticities}

The structural equations of model in this study are all log-linear (or $y=\alpha_{0} \prod^{m} x_{j}^{\alpha_{j}}$ in the natural form) and, therefore, $\alpha_{j}$ may be interpreted as the elasticity of $y$ with respect to $x_{j}$. The sum total of elasticities $\left(s=\sum_{j=1}^{m} a_{j}\right)$ determines the degree of homogeneity of a function. If every $x_{j}$ is multiplies by a constant (say, $\lambda$ ) then $y$ will be multiplies by $\lambda^{s}$. The Table- 1 below presents the sum of elasticities for different endogenous variables under the alternative procedures of estimation. The sum of elasticities for E1, E2, S2, P, HD15, GI10 and SP16 are all below unity. A 10\% increase $(\lambda=1.1)$ in the present values of their predictors would give rise to less than $10 \%$ (or $\lambda^{s} ; 0<\mathrm{s}<1$ ) increase in the quantity of those response variables. The elasticity in case of P and GI are only slightly more than 0.5 . However, the value of $s$ for S3, DI and CP is greater than unity and, therefore, $10 \%$ increase in the present values of their predictors would give rise to greater than $10 \%$ ( or $\lambda^{s} ; \mathrm{s}>1$ ) increase in the quantity of those endogenous (response) variables. It suggests that $\mathrm{CP}$ is elastic and $\mathrm{S} 3$ is hyper-elastic $(s>5)$. As to $\mathrm{S} 1$ the conventional 2-SLS and 
Shapley value based 2-SLS give quite different results. However, in view of better performance of the latter, one may conclude that $\mathrm{S} 1$ is elastic (since $\mathrm{s}$ for both the scenarios is greater than unity). These results clearly suggest that even if the pace of globalization would be tapering off over time, its impacts on trans-border personal connections (S1), acculturation or cultural proximity, democratization (DI) and social capital (corruption perception, $\mathrm{CP}$ ) will continue increasing with acceleration. It may suggest that globalization will have more impact on socio-cultural and political spheres than economic sphere.

\begin{tabular}{lcccccccccccc}
\hline Scenario & Estimator & $\mathrm{E} 1$ & $\mathrm{E} 2$ & $\mathrm{~S} 1$ & $\mathrm{~S} 2$ & $\mathrm{~S} 3$ & $\mathrm{P}$ & $\mathrm{DI}_{16}$ & $\mathrm{CP}_{16}$ & $\mathrm{HD}_{15}$ & $\mathrm{GI}_{10}$ & $\mathrm{SP}_{16}$ \\
\hline \multirow{2}{*}{$\begin{array}{l}\text { Pessimistic } \\
\text { Scenario }\end{array}$} & $\begin{array}{c}\text { Conven- } \\
\text { tional }\end{array}$ & 0.7063 & 0.8458 & 0.6519 & 0.7609 & 5.9947 & 0.0686 & 2.6742 & 1.1974 & 0.9151 & 0.5790 & 0.8421 \\
\cline { 2 - 11 } & Shapley & 0.7757 & 0.8099 & 1.2750 & 0.8226 & 5.2738 & 0.2692 & 1.3885 & 1.0830 & 0.6364 & 0.6310 & 0.6748 \\
\hline \multirow{2}{*}{$\begin{array}{l}\text { Optimistic } \\
\text { Scenario }\end{array}$} & $\begin{array}{c}\text { Conven- } \\
\text { tional }\end{array}$ & 0.3063 & 0.3800 & 0.8177 & 0.5881 & 7.1938 & 0.2804 & 1.9922 & 1.5267 & 0.8033 & 0.5126 & 0.8271 \\
\cline { 2 - 11 } & Shapley & 0.4720 & 0.8216 & 1.3630 & 0.7564 & 5.7191 & 0.2566 & 1.4415 & 1.3831 & 0.7673 & 0.5377 & 0.7097 \\
\hline
\end{tabular}

Table-1. Degree of homogeneity or Sum of Elasticities (the Structural Coefficients) for Endogenous Variable

\section{CONCLUDING REMARKS}

The present study purported to investigate into the relationship among globalization, political regime type, human capital, social capital and social progress. A literature survey suggested differing views of the scholars, supported by arguments as well as empirical findings. Suggestions abound that hinted at bi-directional causality among the variables of interest.

The study formulated a simultaneous equation model connecting globalization, political regime type, human capital, corruption, per capita income and the social progress index. The specification of the model depended partly on the literature review and partly on reasoning. As to the structural equations, the endogenous variables were conceived to be connected to the predictor variables in a log-linear form. The model was estimated by the conventional 2-SLS method. It was found that the structural coefficients of the model were poorly estimated by the conventional 2-SLS owing to collinearity among the predictor variables. When the collinearity problem was treated by using the Shapley value regression (at the second stage of 2-SLS) much better and unambiguous results were obtained. All the estimated structural parameters bore the expected sign. Additionally, only a few of them were significant at $10 \%$ or $5 \%$ while most of them were significant at $1 \%$ level of significance. On the ground of the findings, it may be asserted that in predicting globalization FOG, PPN and EPP have been relatively weaker than other two (PCL and CVL) measures of regime type. On the other side, globalization affects democracy, social capital, human capital and social progress positively and in a statistically significant manner.

The findings confirm that globalization measures are consistent and conformal among themselves. Globalization positively influences and is influenced by democracy, human development and social capital. Globalization reduces corrupt practices and integrity promotes globalization. Finally, democracy, social capital (integrity) human development and globalization affect social progress positively. It has also been found that trans-border personal connection (S1), cultural proximity (S3) democracy (DI) and social capital (CP) are elastic (with the degree of homogeneity larger than unity) with respect to their predictors. 
As a policy consideration, the findings suggest that economic globalization requires more political support, especially in matters of the functioning of the government, political participation by the people or people's representatives on their behalf and pluralistic political climate. It will curb the practices discouraging economic globalization. Social globalization is likely to follow the suit automatically.

In spite of notable and statistically significant findings, the present study has several limitations. First of all, the model does not include many variables (such as physical and financial capital, freedom index, innovation index, income inequalities, etc.) explicitly since it assumes that per capita income and the level of human development incorporate them indirectly. Incorporation of such relevant variables explicitly may shed more light on the relationships studied here. Similarly, institutions are indirectly represented by political regime and corruption perception index. However, many potent measures of social institutions can be included. Corruption is only a minor measure of social capital. The scope of social capital is vast and it requires many more indicators to represent it.

As to estimation of the model, it has been accomplished by a method that ignores correlation among the residuals of the endogenous variables across the equations. It directly speaks on the efficiency of estimation. System methods of estimation together with more concern shown to specification of the model in every equation may be the next step to refine the present work.

\section{REFERENCES}

Acemoglu, D. and Robinson, J.A. (2006a). Economic Backwardness in Political Perspective. American Political Science Review, 100(1), 115-131.

Acemoglu, D., and Robinson, J. A. (2006b). Economic Origins of Dictatorship and Democracy. Cambridge, Mass: Cambridge University Press.

Adelman, I. and Morris, C, (1967). Society, Politics and Economic Development. Baltimore, Johns Hopkins University Press.

Ades, A. and Di Tella, R. (1997) The new economics of corruption: a survey and some new results, Political Studies, XLV, 496-515.

Ades, A., and Di Tella, R. (1999) Rents, competition and corruption. The American Economic Review, 89 (4), 982-993.

Asongu, S.A. (2012). Globalization and Africa: implications for human development. MPRA Paper No. 36546, https://mpra.ub.uni-muenchen.de/36546/

Badinger, H. and Nin, E. (2014). Globalisation and Corruption, Revisited. The World Economy, 37(10), 1424-1440.

Ball, S. (2005). The Commercialisation of Education in England: Towards a New Form of Social Relations. Keynote address to the Japan-UK Education Forum, Kyoto.

Barro, R. J. (1997). Determinants of Economic Growth. A Cross-Country Empirical Study. Cambridge, MA,The MIT Press.

Barro, R.J. (1989). A cross-country study of growth, saving, and government. NBER Working Paper No. 2855. http://www.nber.org/papers/w2855. Cambridge, National Bureau of Economic Research.

Bayer, Y. and Alakbarov, N. (2016). Corruption and foreign direct investment in emerging market economies. Ecoforum, 5(2:9), 303-308.

Boix, C. (2003). Democracy and Redistribution. New York, Cambridge University Press.

Brunetti, A. and Weder, B. (2003) A free press is bad news for corruption. Journal of Public Economics, 87(7-8), 1801-1824.

Das, J. and DiRienzo, E. (2009). The Nonlinear Impact of Globalization on Corruption. The International Journal of Business and Finance Research, 3(2), 33-46. 
Dick, W.G. (1974). Authoritarian versus Nonauthoritarian Approaches to Economic Development. Journal of Political Economy, 82(4): 817-27.

Dreher, A. (2006). Does Globalization Affect Growth? Evidence from a new Index of Globalization. Applied Economics, 38(10), 1091-1110.

Dreher, A., Gaston, N. and Martens, P. (2008). Measuring Globalisation: Gauging its Consequences. New York: Springer.

Durkheim, E. (1997). The Division of Labour in Society. (Trans. W. D. Halls, intro. Lewis A. Coser). New York, Free Press.

Eichengreen, B. and Leblang, D. (2006). Democracy and Globalization. NBER Working Paper 12450. Cambridge, Mass: National Bureau of Economic Research.

Eisner, M. (1995). The state in the American political economy. Englewood Cliffs, NJ: Prentice Hall.

Elliott, K.A. (1997) Corruption as an International Policy Problem: Overview and Recommendations, in Kimberly Ann Elliott (ed.), Corruption and the Global Economy, 175-233, (Washington, DC: Institute For International Economics, 1997).

Ewoh, A.I.E., Matei, A. and Matei, L. (2013). Corruption, public integrity, and globalization in South-Eastern European states. A comparative analysis. Theoretical and Applied Economics, 20(1:578), 7-34.

Figueroa, A.M. (2014).The impact of globalization on human development in the developing countries: the case of Central and South America. Revista Eletrônica de Ciência Política, 5(2), 24-41.

Golden, M. (2002) Does globalization reduce corruption? Some political consequences of economic integration. Unpublished Paper. http://www.sppsr.ucla.edu/cgpr/docs/ MiriamGoldenpaper.pdf

Gould, D. (1991). Administrative corruption: Incidence, causes, and remedial strategies. In A. Farazmand (Ed.), Handbook of comparative and development public administration. New York: Marcel Dekker, pp. 467-484.

Grier, K.B. and Tullock, G. (1989). An empirical analysis of cross-national economic growth, 1951-80. Journal of Monetary Economics, 24(2), 259-76.

Haffoudhi, H. and Bellakhal, R. (2016). Threshold Effect of Globalization on Democracy: The Role of Demography. SSRN: https://ssrn.com/abstract=2906308.

Halperin, M.H., Siegle, J.T. and Weinstein, M.M. (2005). The Democracy Advantage: How Democracies Promote Prosperity and Peace. New York, Routledge.

Hanifan, L. J. (1916). The Rural School Community Center. Annals of the American Academy of Political and Social Science, 67(1), 130-138.

Hayek, F.A. (1960). The Constitution of Liberty. Chicago: University of Chicago Press.

Hegre, H. and Fjelde, H. (2008). Democracy Depraved: Political Corruption and Institutional Transitions. Paper presented at the Norwegian National Political Science Conference, Tromsø, 28 ${ }^{\text {th }}-30^{\text {th }}$ April, 2008.

Helliwell, J.F. (1992). Empirical linkages between democracy and economic growth. NBER Working Paper \# 4066. National Bureau of Economic Research, Cambridge. Published as Helliwell, J.F. (1994). Empirical Linkages Between Democracy and Economic Growth. British Journal of Political Science, 24(2), 225-248.

Herzfeld, T. and Weiss, C. (2003) Corruption and legal (in)-effectiveness: An empirical investigation. European Journal of Political Economy 19(3), 621-632.

Hirsch F. (1977). Social Limits to Growth. London: Routledge and Kegan Paul.

Huntington, S.P. and Jorge, I.D. (1975). Political Development. In Greenstein, F. I. and N. W. Polsby, N.W. (1975) eds. Handbook of Political Science. 3. Reading: Boston, Addison-Wesley, 1-114.

Huynen, M.M., Martens, P. and Hilderink, H.B.M. (2005). The health impacts of globalisation: A conceptual framework. Global Health, 1(14). https://www.ncbi.nlm.nih.gov/pmc/articles/C1208931/ pdf/1744-8603-1-14.pdf

Jreisat, J. (1997) Politics without process: Administering development in the Arab world. Boulder, Co: Lynne Reinner.

Keynes, J. M. (1926). The End of Laissez-Faire. In Collected Writings (of J.M. Keynes), Volume 9, (1971-73), London: St Martin. See https://www.panarchy.org/keynes/laissezfaire.1926.html. 
Knutsen, C.H. (2007). Democracy and Property Rights - A theoretical and empirical analysis on the effects of political regime type on property rights arrangements. Master's Thesis, Department of Economics, Oslo, University of Oslo.

Knutsen, C.H. (2008a). From James Monroe and the Quing Dynasty to George W. Bush and the Communist Party: The historical evidence on how democracy and dictatorship affect economic growth. Working Paper. Department of Political Science, Oslo, University of Oslo.

Knutsen, C.H. (2008b). The Economic Effects of Democracy - An Empirical Analysis. Working Paper, Department of Political Science, Oslo, University of Oslo.

Knutsen, C.H. (2010). Investigating the Lee-thesis: How bad is democracy for Asian economies? European Political Science Review, 2(3), 451-473. [Original manuscript of the paper (2009) at http://www.ibrarian.net/navon/ paper/Investigating_the_Lee_thesis_How_bad_is_democrac.pdf?paperid=13409918].

KOF [Konjunkturforschungsstelle or Economic Research Centre of ETH Zurich]. (2017). 2017 Index of globalization. http://globalization.kof.ethz.ch/media/filer_public/2017/04/19/rankings_2017.pdf

Kohli, A. (1986). Democracy and Development. In Lewis, J.P. and Kallab, V. (1986) eds. Development Strategies Reconsidered. New Brunwick, Transaction Books, 153-82.

Kollias, C. and Paleologou, S.M. (2016). Globalization and Democracy: A Disaggregated Analysis by Income Group. Global Economy Journal, 16(2), 213-228.

Kormendi, R.C. and Meguire, P.G. (1985). Macroeconomic Determinants of Growth: Cross-Country Evidence. Journal of Monetary Economics, 16(2), 141-63.

Lake, D.A. and Baum, M.A. (2001). The Invisible Hand of Democracy: Political Control and the Provision of Public Services. Comparative Political Studies, 34(6), 587-621.

Lalountas, D.A., Manolas, G.A. and Ioannis, S.V. (2011). Corruption, globalization and development: How are these three phenomena related? Journal of Policy Modeling, 33(4), 636-648.

Landau, D. (1986). Government and Economic Growth in the Less Developed Countries: An Empirical Study for 1960-1980. Economic Development and Cultural Change, 35(1), 35-75.

Leblang, D.A. (1997). Political Democracy and Economic Growth: Pooled Cross-Sectional and Times-Series Evidence. British Journal of Political Science, 27 (3), 453-472.

Lee, E. and Vivarelli, M. (2006). The Social Impact of Globalization in the Developing Countries. IZA DP No. 1925, Institute for the Study of Labor, Bonn, Germany.

Leiken, R. S. (1997) Controlling the global corruption epidemic. Foreign Policy, Winter, 55-73.

Li, Q. and Reuveny, R. (2003). Economic Globalization and Democracy: An Empirical Analysis. British Journal of Political Science, 33(1), 29-54.

Lipovetsky, S. (2006). Entropy Criterion in Logistic Regression and Shapley Value of Predictors. Journal of Modern Applied Statistical Methods, 5(1), 95-106.

Lipset, S.M. (1959). Some Social Requisites of Democracy: Economic Development and Political Legitimacy. American Political Science Review, 53(1), 69-105.

Marsh, R.M. (1979). Does democracy hinder economic development in the latecomer developing nations? Comparative Social Research, 2(2), 215-48.

Milner, H.V. and Mukherjee, B. (2009). Democratization and Economic Globalization. Annual Review Political Science, 12(1), 163-181.

Mishra, S.K. (2016a). Shapley Value Regression and the Resolution of Multicollinearity. Journal of Economics Bibliography, 3(3), 498-515.

Mishra, S.K. (2016b). A Note on Construction of a Composite Index by Optimization of Shapley Value Shares of the Constituent Variables. Turkish Economic Review, 3(3), 466-472.

Mishra, S.K. (2017). Trends in Globalization of Select Asian Countries. Journal of Economic and Social Thought, $4(4), 451-466$. 
Mishra, S.K. (2018). A Study on Regime Type and Globalization in Simultaneous Equation Framework. Journal of Economics and Financial Analysis, 2(1), 99-128.

Myrdal, G. (1972). Asian Drama: An Inquiry into the Poverty of Nations. (Abridged version by S.S. King of The Twentieth Century Fund Study). New York, Vintage Books.

Naqvi, S.N.H. (2002). Globalization and human development: An overview. In Perspectives and Overview of Life Support Systems and Sustainable Development, Vol-II, Encyclopedia of Life Support Systems (UNESCOEOLSS). Paris; UNESCO.

Pourgerami, A. (1988). The political economy of development: A cross-national causality test of developmentdemocracy-growth hypothesis. Public Choice, 58(2), 123-41.

Pourgerami, A. (1991). The political economy of development. An empirical investigation of the wealth theory of democracy. Journal of Theoretical Politics, 3(2), 189-211.

Przeworski, A. (1966). Party Systems and Economic Development. Ph.D. dissertation: Illinois, North- western University.

Przeworski, A. and Limongi, F. (1993). Political Regimes and Economic Growth. The Journal of Economic Perspectives, 7(3), 51-69.

Rabbanee, F.K., Haque, M.M. and Hasan, F. (2010). Globalization and Human Development - Realities and Recommendations for Developing Countries. Asian Affairs, 30(1), 32-49.

Reiersøl, O. (1945). Confluence Analysis by Means of Instrumental Sets of Variables. Arkiv for Mathematic, Astronomi, och Fysik. 32A. Uppsala: Almquist \& Wiksells.

Remmer, K. (1990). Democracy and economic crisis: the Latin American experience. World Politics, 42(3), 315-35.

Rodrik, D. (1998). Democracies Pay Higher Wages. NBER Working Paper No. 6364. National Bureau of Economic Research, Cambridge, Mass. http://www.nber.org/papers/w6364.

Rudra, N. (2005). Globalization and the Strengthening of Democracy in the Developing World. American Journal of Political Science, 49(4), 704-730.

Sabi, M. (2007).Globalization and Human Development. International Conference on Globalization and Its Discontents, Cortland. http://eco.ieu.edu.tr/wp-content/proceedings/2007/0707.pdf

Sapkota, J.B. (2011). Globalization and Human Aspect of Development in Developing Countries: Evidence from Panel Data. Journal of Globalization Studies, 2(1), 78-96. https://www.socionauki.ru/journal/articles/132655/

Schumpeter, J.A. (1950). Capitalism, Socialism and Democracy. New York: Harper \& Row.

Schwartzman, K.C. (1998). Globalization and democracy. Annual Review of Sociology, 24(1), 159-81.

Scully, G.W. (1988). The Institutional Framework and Economic Development. Journal of Political Economy, 96(3), 652-62.

Scully, G.W. (1992). Constitutional Environments and Economic Growth. Princeton, Princeton University Press. Sen, A.K. (1999). Development as freedom. New York, Oxford University Press.

Singer, H. W. (1950). The distribution of gains between investing and borrowing countries. American Economic Review, 40(2), 473-485.

Sirageldin, I. (2002). Sustainable Human Development in the Twenty-First Century: An Evolutionary Perspective. In Perspectives and Overview of Life Support Systems and Sustainable Development, Encyclopedia of Life Support Systems (UNESCO-EOLSS). Paris; UNESCO.

Sloan, J. and Tedin, K.T. (1987). The Consequences of Regimes Type for Public-Policy Outputs. Comparative Political Studies, 20(1), 98-124.

Smith, G., and Brainard, W. (1976). The Value of a priori Information in Estimating a Financial Model. Journal of Finance, 31(5), 1299-1322.

Sobhan, R. (2003). Globalization and the Challenge to Democracy. International Journal of Development Issues, 2(2), 1-14.

Stein, A.A. (2016). The Great Trilemma: Are Globalization, Democracy, and Sovereignty Compatible? International Theory, 8(2), 297-340. 
Steiner, N.D. (2015). Essays on Globalization and Democracy. D. Phil dissertation, vorgelegt dem Fachbereich 02 - Sozialwissenschaften, Medien und Sport der Johannes Gutenberg Univ., Mainz. https://nilssteiner.com/ wp-content/uploads/2017/01/Dissertation_Steiner_Introduction-only.pdf

Stiglitz, J.E., Sen, A. and Fitoussi, J. (2009). The measurement of economic performance and social progress revisited. OFCE - Centre de recherche en économie de Sciences Po, France.

Storn, R. and Price, K. (1997). Differential evolution - a simple and efficient heuristic for global optimization over continuous spaces. Journal of Global Optimization, 11(4), 341-359.

Streeten, P. (1998). Globalization: threat or opportunity. Pakistan Development Review, 37(4), 51-85.

Treisman, D. (2000) The causes of corruption: A cross-national study. Journal of Public Economics 76(3), 399-457.

Tsai, M.C. (2006). Does Globalization Affect Human Well-being? Paper presented in XVI ISA World Congress of Sociology (WG06 Social Indicators Session), July 23-29, 2006 in Durban, South Africa. https://pdfs.semanticscholar.org/1720/acc411e5437f6ecf0b6319fb79c50dde08dd.pdf

Turyahikayo, E. (2014). The Impact of Globalization on Domestic Political Structures in Established, Transitional and Non-Democracies. Journal of Good Governance and Sustainable Development in Africa, 2(2), 94-109.

Weede, E. (1983). The Impact of Democracy on Economic Growth: Some Evidence from Cross-National Analysis. Kyklos, 36(1), 21-39.

Yang, R. (2006). The Commodification of Education and Its Effects on Developing Countries: A Focus on China. Journal für Entwicklungpolitik, 22(4), 52-69.

\section{APPENDIX}

\section{[DATA USED IN THE PRESENT STUDY]}

\begin{tabular}{|c|c|c|c|c|c|c|c|c|}
\hline \multirow{2}{*}{ SL } & \multirow{2}{*}{ Country } & \multicolumn{5}{|c|}{ Dimensions of Democracy - 2006} & \multirow{2}{*}{$\begin{array}{c}\text { Democrac } \\
\begin{array}{c}\text { Index } \\
2006\end{array} \\
\mathrm{DI}_{06}\end{array}$} & \multirow{2}{*}{$\begin{array}{c}\text { Index } \\
2016 \\
\mathrm{DI}_{16}\end{array}$} \\
\hline & & EPP & FOG & PPN & PCL & CVL & & \\
\hline 1 & Albania & 7.33 & 5.07 & 4.44 & 5.63 & 7.06 & 5.91 & 5.91 \\
\hline 2 & Argentina & 8.75 & 5.00 & 5.56 & 5.63 & 8.24 & 6.63 & 6.96 \\
\hline 3 & Australia & 10.00 & 8.93 & 7.78 & 8.75 & 10.00 & 9.09 & 9.01 \\
\hline 4 & Austria & 9.58 & 8.21 & 7.78 & 8.75 & 9.12 & 8.69 & 8.41 \\
\hline 5 & Azerbaijan & 3.08 & 0.79 & 3.33 & 3.75 & 5.59 & 3.31 & 2.65 \\
\hline 6 & Burundi & 4.42 & 3.29 & 3.89 & 6.25 & 4.71 & 4.51 & 2.40 \\
\hline 7 & Belgium & 9.58 & 8.21 & 6.67 & 6.88 & 9.41 & 8.15 & 7.77 \\
\hline 8 & Benin & 6.83 & 6.43 & 3.89 & 6.88 & 6.76 & 6.16 & 5.67 \\
\hline 9 & Burkina_Faso & 4.00 & 1.79 & 2.78 & 5.63 & 4.41 & 3.72 & 4.70 \\
\hline 10 & Bulgaria & 9.58 & 5.71 & 6.67 & 5.00 & 8.53 & 7.10 & 7.01 \\
\hline 11 & Bolivia & 8.33 & 5.71 & 4.44 & 3.75 & 7.65 & 5.98 & 5.63 \\
\hline 12 & Brazil & 9.58 & 7.86 & 4.44 & 5.63 & 9.41 & 7.38 & 6.90 \\
\hline 13 & Bhutan & 0.08 & 4.64 & 1.11 & 3.75 & 3.53 & 2.62 & 4.93 \\
\hline 14 & Botswana & 9.17 & 7.86 & 5.00 & 6.88 & 9.12 & 7.60 & 7.87 \\
\hline 15 & C._Afr_Rep & 0.42 & 1.43 & 1.67 & 1.88 & 2.65 & 1.61 & 1.61 \\
\hline 16 & Canada & 9.17 & 9.64 & 7.78 & 8.75 & 10.00 & 9.07 & 9.15 \\
\hline 17 & Switzerland & 9.58 & 9.29 & 7.78 & 8.75 & 9.71 & 9.02 & 9.09 \\
\hline
\end{tabular}




\begin{tabular}{|c|c|c|c|c|c|c|c|c|}
\hline 18 & Chile & 9.58 & 8.93 & 5.00 & 6.25 & 9.71 & 7.89 & 7.78 \\
\hline 19 & China & 0.00 & 4.64 & 2.78 & 6.25 & 1.18 & 2.97 & 3.14 \\
\hline 20 & Cote_d'Ivoire & 1.25 & 2.86 & 3.33 & 5.63 & 3.82 & 3.38 & 3.81 \\
\hline 21 & Cameroon & 0.92 & 3.21 & 2.78 & 5.63 & 3.82 & 3.27 & 3.46 \\
\hline 22 & Congo_Rep. & 4.58 & 0.36 & 2.78 & 3.75 & 2.35 & 2.76 & 2.91 \\
\hline 23 & Colombia & 9.17 & 4.36 & 5.00 & 4.38 & 9.12 & 6.40 & 6.67 \\
\hline 24 & Costa_Rica & 9.58 & 8.21 & 6.11 & 6.88 & 9.41 & 8.04 & 7.88 \\
\hline 25 & Cyprus & 9.17 & 6.79 & 6.67 & 6.25 & 9.12 & 7.60 & 7.65 \\
\hline 26 & Germany & 9.58 & 8.57 & 7.78 & 8.75 & 9.41 & 8.82 & 8.63 \\
\hline 27 & Denmark & 10.00 & 9.64 & 8.89 & 9.38 & 9.71 & 9.52 & 9.20 \\
\hline 28 & Domin_Rep & 9.17 & 4.29 & 3.33 & 5.63 & 8.24 & 6.13 & 6.67 \\
\hline 29 & Algeria & 2.25 & 2.21 & 2.22 & 5.63 & 3.53 & 3.17 & 3.56 \\
\hline 30 & Ecuador & 7.83 & 4.29 & 5.00 & 3.13 & 7.94 & 5.64 & 5.81 \\
\hline 31 & Egypt & 2.67 & 3.64 & 2.78 & 6.88 & 3.53 & 3.90 & 3.31 \\
\hline 32 & Spain & 9.58 & 7.86 & 6.11 & 8.75 & 9.41 & 8.34 & 8.30 \\
\hline 33 & Ethiopia & 4.00 & 3.93 & 5.00 & 6.25 & 4.41 & 4.72 & 3.60 \\
\hline 34 & Finland & 10.00 & 10.00 & 7.78 & 8.75 & 9.71 & 9.25 & 9.03 \\
\hline 35 & Fiji & 6.50 & 5.21 & 3.33 & 5.00 & 8.24 & 5.66 & 5.64 \\
\hline 36 & France & 9.58 & 7.50 & 6.67 & 7.50 & 9.12 & 8.07 & 7.92 \\
\hline 37 & Gabon & 0.50 & 3.21 & 2.22 & 5.63 & 2.06 & 2.72 & 3.74 \\
\hline 38 & U.K. & 9.58 & 8.57 & 5.00 & 8.13 & 9.12 & 8.08 & 8.36 \\
\hline 39 & Ghana & 7.42 & 4.64 & 4.44 & 4.38 & 5.88 & 5.35 & 6.75 \\
\hline 40 & Guinea & 1.00 & 0.79 & 2.22 & 3.75 & 2.35 & 2.02 & 3.14 \\
\hline 41 & Gambia & 4.00 & 4.64 & 4.44 & 5.63 & 3.24 & 4.39 & 2.91 \\
\hline 42 & Greece & 9.58 & 7.50 & 6.67 & 7.50 & 9.41 & 8.13 & 7.23 \\
\hline 43 & Guatemala & 8.75 & 6.79 & 2.78 & 4.38 & 7.65 & 6.07 & 5.92 \\
\hline 44 & Guyana & 8.33 & 5.36 & 4.44 & 4.38 & 8.24 & 6.15 & 6.25 \\
\hline 45 & Honduras & 8.33 & 6.43 & 4.44 & 5.00 & 7.06 & 6.25 & 5.92 \\
\hline 46 & Haiti & 5.58 & 3.64 & 2.78 & 2.50 & 6.47 & 4.19 & 4.02 \\
\hline 47 & Hungary & 9.58 & 6.79 & 5.00 & 6.88 & 9.41 & 7.53 & 6.72 \\
\hline 48 & Indonesia & 6.92 & 7.14 & 5.00 & 6.25 & 6.76 & 6.41 & 6.97 \\
\hline 49 & India & 9.58 & 8.21 & 5.56 & 5.63 & 9.41 & 7.68 & 7.81 \\
\hline 50 & Ireland & 9.58 & 8.93 & 7.78 & 8.75 & 10.00 & 9.01 & 9.15 \\
\hline 51 & Iceland & 10.00 & 9.64 & 8.89 & 10.00 & 10.00 & 9.71 & 9.50 \\
\hline 52 & Israel & 9.17 & 6.64 & 7.78 & 7.50 & 5.29 & 7.28 & 7.85 \\
\hline 53 & Italy & 9.17 & 6.43 & 6.11 & 8.13 & 8.82 & 7.73 & 7.98 \\
\hline 54 & Jamaica & 9.17 & 7.14 & 5.00 & 6.25 & 9.12 & 7.34 & 7.39 \\
\hline 55 & Jordan & 3.08 & 3.79 & 3.89 & 5.00 & 3.82 & 3.92 & 3.96 \\
\hline 56 & Japan & 9.17 & 7.86 & 5.56 & 8.75 & 9.41 & 8.15 & 7.99 \\
\hline
\end{tabular}




\begin{tabular}{|c|c|c|c|c|c|c|c|c|}
\hline 57 & Kenya & 4.33 & 4.29 & 5.56 & 6.25 & 5.00 & 5.08 & 5.33 \\
\hline 58 & Cambodia & 5.58 & 6.07 & 2.78 & 5.00 & 4.41 & 4.77 & 4.27 \\
\hline 59 & South_Korea & 9.58 & 7.14 & 7.22 & 7.50 & 7.94 & 7.88 & 7.92 \\
\hline 60 & Kuwait & 1.33 & 4.14 & 1.11 & 5.63 & 3.24 & 3.09 & 3.85 \\
\hline 61 & Lebanon & 7.92 & 2.36 & 6.11 & 6.25 & 6.47 & 5.82 & 4.86 \\
\hline 62 & Lesotho & 7.92 & 6.43 & 4.44 & 6.25 & 7.35 & 6.48 & 6.59 \\
\hline 63 & Luxembourg & 10.00 & 9.29 & 7.78 & 8.75 & 9.71 & 9.10 & 8.81 \\
\hline 64 & Morocco & 3.50 & 3.79 & 2.78 & 5.63 & 3.82 & 3.90 & 4.77 \\
\hline 65 & Moldova & 9.17 & 4.29 & 6.11 & 5.00 & 7.94 & 6.50 & 6.01 \\
\hline 66 & Madagascar & 5.67 & 5.71 & 5.56 & 6.88 & 5.29 & 5.82 & 5.07 \\
\hline 67 & Mexico & 8.75 & 6.07 & 5.00 & 5.00 & 8.53 & 6.67 & 6.47 \\
\hline 68 & Mali & 8.25 & 5.71 & 3.89 & 5.63 & 6.47 & 5.99 & 5.70 \\
\hline 69 & Malta & 9.17 & 8.21 & 6.11 & 8.75 & 9.71 & 8.39 & 8.39 \\
\hline 70 & Myanmar & 0.00 & 1.79 & 0.56 & 5.63 & 0.88 & 1.77 & 4.20 \\
\hline 71 & Montenegro & 9.17 & 5.71 & 5.00 & 5.63 & 7.35 & 6.57 & 5.72 \\
\hline 72 & Mongolia & 9.17 & 6.07 & 3.89 & 5.63 & 8.24 & 6.60 & 6.62 \\
\hline 73 & Mauritania & 1.83 & 4.29 & 2.22 & 3.13 & 4.12 & 3.12 & 3.96 \\
\hline 74 & Mauritius & 9.17 & 8.21 & 5.00 & 8.13 & 9.71 & 8.04 & 8.28 \\
\hline 75 & Malawi & 6.00 & 5.00 & 3.89 & 4.38 & 5.59 & 4.97 & 5.55 \\
\hline 76 & Malaysia & 6.08 & 5.71 & 4.44 & 7.50 & 6.18 & 5.98 & 6.54 \\
\hline 77 & Niger & 5.25 & 1.14 & 1.67 & 3.75 & 5.88 & 3.54 & 3.96 \\
\hline 78 & Nigeria & 3.08 & 1.86 & 4.44 & 4.38 & 3.82 & 3.52 & 4.50 \\
\hline 79 & Nicaragua & 8.25 & 5.71 & 3.33 & 3.75 & 7.35 & 5.68 & 4.81 \\
\hline 80 & Netherlands & 9.58 & 9.29 & 9.44 & 10.00 & 10.00 & 9.66 & 8.80 \\
\hline 81 & Norway & 10.00 & 9.64 & 10.00 & 8.13 & 10.00 & 9.55 & 9.93 \\
\hline 82 & Nepal & 0.08 & 3.57 & 2.22 & 5.63 & 5.59 & 3.42 & 4.86 \\
\hline 83 & New_Zealand & 10.00 & 8.57 & 8.33 & 8.13 & 10.00 & 9.01 & 9.26 \\
\hline 84 & Pakistan & 4.33 & 5.36 & 0.56 & 4.38 & 5.00 & 3.92 & 4.33 \\
\hline 85 & Panama & 9.58 & 7.14 & 5.56 & 5.63 & 8.82 & 7.35 & 7.13 \\
\hline 86 & Peru & 8.75 & 3.29 & 5.56 & 5.00 & 7.94 & 6.11 & 6.65 \\
\hline 87 & Philippines & 9.17 & 5.36 & 5.00 & 3.75 & 9.12 & 6.48 & 6.94 \\
\hline 88 & Poland & 9.58 & 6.07 & 6.11 & 5.63 & 9.12 & 7.30 & 6.83 \\
\hline 89 & Portugal & 9.58 & 8.21 & 6.11 & 7.50 & 9.41 & 8.16 & 7.86 \\
\hline 90 & Paraguay & 7.92 & 5.00 & 5.00 & 4.38 & 8.53 & 6.16 & 6.27 \\
\hline 91 & Romania & 9.58 & 6.07 & 6.11 & 5.00 & 8.53 & 7.06 & 6.62 \\
\hline 92 & Rwanda & 3.00 & 3.57 & 2.22 & 5.00 & 5.29 & 3.82 & 3.07 \\
\hline 93 & Saudi_Arabia & 0.00 & 2.36 & 1.11 & 4.38 & 1.76 & 1.92 & 1.93 \\
\hline 94 & Senegal & 7.00 & 5.00 & 3.33 & 5.63 & 5.88 & 5.37 & 6.21 \\
\hline 95 & Singapore & 4.33 & 7.50 & 2.78 & 7.50 & 7.35 & 5.89 & 6.38 \\
\hline
\end{tabular}




\begin{tabular}{|c|c|c|c|c|c|c|c|c|}
\hline 96 & Sierra_Leone & 5.25 & 2.21 & 2.22 & 3.75 & 4.41 & 3.57 & 4.55 \\
\hline 97 & El_Salvador & 9.17 & 5.43 & 3.89 & 4.38 & 8.24 & 6.22 & 6.64 \\
\hline 98 & Sweden & 10.00 & 10.00 & 10.00 & 9.38 & 10.00 & 9.88 & 9.39 \\
\hline 99 & Swaziland & 1.75 & 2.86 & 2.22 & 3.13 & 4.71 & 2.93 & 3.03 \\
\hline 100 & Syr_Arab_Rep & 0.00 & 1.79 & 1.67 & 6.88 & 1.47 & 2.36 & 1.43 \\
\hline 101 & Chad & 0.00 & 0.00 & 0.00 & 5.00 & 3.24 & 1.65 & 1.50 \\
\hline 102 & Togo & 0.00 & 0.79 & 0.56 & 5.63 & 1.76 & 1.75 & 3.32 \\
\hline 103 & Thailand & 4.83 & 6.43 & 5.00 & 5.63 & 6.47 & 5.67 & 4.92 \\
\hline 104 & Trinid \& Tobago & 9.17 & 6.79 & 6.11 & 5.63 & 8.24 & 7.18 & 7.10 \\
\hline 105 & Tunisia & 0.00 & 2.36 & 2.22 & 6.88 & 3.82 & 3.06 & 6.40 \\
\hline 106 & Turkey & 7.92 & 6.79 & 4.44 & 3.75 & 5.59 & 5.70 & 5.04 \\
\hline 107 & Tanzania & 6.00 & 3.93 & 5.06 & 5.63 & 5.29 & 5.18 & 5.76 \\
\hline 108 & Uganda & 4.33 & 3.93 & 4.44 & 6.25 & 6.76 & 5.14 & 5.26 \\
\hline 109 & Uruguay & 10.00 & 8.21 & 5.00 & 6.88 & 9.71 & 7.96 & 8.17 \\
\hline 110 & U.S.A. & 8.75 & 7.86 & 7.22 & 8.75 & 8.53 & 8.22 & 7.98 \\
\hline 111 & Venezuela_RB & 7.00 & 3.64 & 5.56 & 5.00 & 5.88 & 5.42 & 4.68 \\
\hline 112 & Vietnam & 0.83 & 4.29 & 2.78 & 4.38 & 1.47 & 2.75 & 3.38 \\
\hline 113 & Yemen_Rep. & 2.67 & 2.71 & 2.78 & 4.38 & 2.35 & 2.98 & 2.07 \\
\hline 114 & South_Africa & 8.75 & 7.86 & 7.22 & 6.88 & 8.82 & 7.91 & 7.41 \\
\hline 115 & Congo_D_Rep. & 4.58 & 0.36 & 2.78 & 3.75 & 2.35 & 2.76 & 1.93 \\
\hline 116 & Zambia & 5.25 & 4.64 & 3.33 & 6.25 & 6.76 & 5.25 & 5.99 \\
\hline
\end{tabular}

Table-A-1. Scores Obtained by Countries on the Measures in Different Dimensions of Democracy

[Source: https://en.wikipedia.org/wiki/Democracy_Index]

\begin{tabular}{|c|c|c|c|c|c|c|c|c|c|c|c|}
\hline \multirow{2}{*}{ SL\# } & \multirow{2}{*}{ Country } & \multicolumn{2}{|c|}{$\begin{array}{l}\text { Corruption } \\
\text { Perception }\end{array}$} & \multicolumn{2}{|c|}{$\begin{array}{c}\text { Human } \\
\text { Development }\end{array}$} & \multirow{2}{*}{$\begin{array}{l}\text { PC In- } \\
\text { come }\end{array}$} & \multirow{2}{*}{$\begin{array}{c}\begin{array}{c}\text { Social } \\
\text { Pro- } \\
\text { gress }\end{array} \\
\text { SP16 }\end{array}$} & \multicolumn{2}{|c|}{$\begin{array}{c}\text { Democracy } \\
\text { Index }\end{array}$} & \multicolumn{2}{|c|}{$\begin{array}{l}\text { Overall Globali- } \\
\text { zation Index } \\
\text { (AEMC) }\end{array}$} \\
\hline & & СР06 & CP16 & HD06 & HD15 & & & DI06 & DI16 & $\begin{array}{c}\text { GI } \\
(\text { Min) }\end{array}$ & $\begin{array}{c}\text { GI } \\
(\operatorname{Max})\end{array}$ \\
\hline 1 & Albania & 26 & 39 & 7.03 & 7.64 & 4.90 & 69.79 & 5.91 & 59.10 & 50.86 & 61.61 \\
\hline 2 & Argentina & 29 & 36 & 7.88 & 8.27 & 13.70 & 75.20 & 6.63 & 69.60 & 57.09 & 59.19 \\
\hline 3 & Australia & 87 & 79 & 9.18 & 9.39 & 32.00 & 89.13 & 9.09 & 90.10 & 82.24 & 84.03 \\
\hline 4 & Austria & 86 & 75 & 8.60 & 8.93 & 32.90 & 86.60 & 8.69 & 84.10 & 91.36 & 93.95 \\
\hline 5 & Azerbaijan & 24 & 30 & 7.08 & 7.59 & 4.70 & 63.76 & 3.31 & 26.50 & 52.78 & 54.69 \\
\hline 6 & Burundi & 24 & 20 & 3.09 & 4.04 & 0.60 & 37.33 & 4.51 & 24.00 & 26.92 & 34.79 \\
\hline 7 & Belgium & 73 & 77 & 8.71 & 8.96 & 31.90 & 86.19 & 8.15 & 77.70 & 92.32 & 93.75 \\
\hline 8 & Benin & 25 & 36 & 4.38 & 4.85 & 1.10 & 50.03 & 6.16 & 56.70 & 41.61 & 48.99 \\
\hline 9 & Burkina_Faso & 32 & 42 & 3.34 & 4.02 & 1.20 & 49.34 & 3.72 & 47.00 & 41.27 & 49.12 \\
\hline 10 & Bulgaria & 40 & 41 & 7.55 & 7.94 & 9.00 & 72.14 & 7.10 & 70.10 & 69.36 & 76.34 \\
\hline 11 & Bolivia & 27 & 33 & 6.26 & 6.74 & 2.70 & 64.74 & 5.98 & 56.30 & 53.62 & 56.38 \\
\hline
\end{tabular}




\begin{tabular}{|c|c|c|c|c|c|c|c|c|c|c|c|}
\hline 12 & Brazil & 33 & 40 & 7.00 & 7.54 & 8.40 & 71.70 & 7.38 & 69.00 & 55.59 & 58.16 \\
\hline 13 & Bhutan & 60 & 65 & 5.50 & 6.07 & 1.40 & 65.65 & 2.62 & 49.30 & 35.44 & 47.07 \\
\hline 14 & Botswana & 56 & 60 & 6.30 & 6.98 & 10.00 & 67.04 & 7.60 & 78.70 & 49.05 & 60.64 \\
\hline 15 & C._Afr_Rep & 24 & 20 & 3.30 & 3.52 & 1.10 & 30.03 & 1.61 & 16.10 & 34.45 & 37.27 \\
\hline 16 & Canada & 85 & 82 & 8.94 & 9.20 & 32.90 & 89.50 & 9.07 & 91.50 & 86.39 & 87.51 \\
\hline 17 & Switzerland & 91 & 86 & 9.11 & 9.39 & 35.30 & 88.87 & 9.02 & 90.90 & 91.37 & 93.18 \\
\hline 18 & Chile & 73 & 66 & 7.97 & 8.47 & 11.30 & 82.12 & 7.89 & 77.80 & 69.54 & 72.77 \\
\hline 19 & China & 33 & 40 & 6.59 & 7.38 & 6.30 & 62.11 & 2.97 & 31.40 & 55.12 & 56.85 \\
\hline 20 & Cote_d'Ivoire & 21 & 34 & 4.18 & 4.74 & 1.50 & 48.97 & 3.38 & 38.10 & 48.82 & 53.08 \\
\hline 21 & Cameroon & 23 & 26 & 4.56 & 5.18 & 1.90 & 47.22 & 3.27 & 34.60 & 40.16 & 42.75 \\
\hline 22 & Congo_Rep. & 22 & 20 & 5.17 & 5.92 & 0.70 & 49.74 & 2.76 & 29.10 & 47.78 & 57.31 \\
\hline 23 & Colombia & 39 & 37 & 6.75 & 7.27 & 7.10 & 70.84 & 6.40 & 66.70 & 54.44 & 58.23 \\
\hline 24 & Costa_Rica & 41 & 58 & 7.34 & 7.76 & 10.10 & 80.12 & 8.04 & 78.80 & 61.03 & 63.45 \\
\hline 25 & Cyprus & 56 & 55 & 8.36 & 8.56 & 20.30 & 80.75 & 7.60 & 76.50 & 78.44 & 89.36 \\
\hline 26 & Germany & 80 & 81 & 8.98 & 9.26 & 29.80 & 86.42 & 8.82 & 86.30 & 85.16 & 87.44 \\
\hline 27 & Denmark & 95 & 90 & 9.04 & 9.25 & 33.40 & 89.40 & 9.52 & 92.00 & 88.85 & 91.90 \\
\hline 28 & Domin_Rep & 28 & 31 & 6.85 & 7.22 & 6.60 & 65.66 & 6.13 & 66.70 & 55.44 & 67.20 \\
\hline 29 & Algeria & 31 & 34 & 6.90 & 7.45 & 7.20 & 61.19 & 3.17 & 35.60 & 42.36 & 53.32 \\
\hline 30 & Ecuador & 23 & 31 & 6.96 & 7.39 & 3.90 & 69.57 & 5.64 & 58.10 & 51.64 & 56.77 \\
\hline 31 & Egypt & 33 & 34 & 6.44 & 6.91 & 4.40 & 60.75 & 3.90 & 33.10 & 53.67 & 59.62 \\
\hline 32 & Spain & 68 & 58 & 8.49 & 8.84 & 25.20 & 85.88 & 8.34 & 83.00 & 84.60 & 86.71 \\
\hline 33 & Ethiopia & 24 & 34 & 3.62 & 4.48 & 0.80 & 43.50 & 4.72 & 36.00 & 37.47 & 39.87 \\
\hline 34 & Finland & 96 & 89 & 8.73 & 8.95 & 30.60 & 90.10 & 9.25 & 90.30 & 85.04 & 87.36 \\
\hline 35 & Fiji & 40 & 40 & 6.98 & 7.36 & 6.10 & 66.50 & 5.66 & 56.40 & 57.81 & 61.30 \\
\hline 36 & France & 74 & 69 & 8.73 & 8.97 & 30.00 & 84.79 & 8.07 & 79.20 & 87.32 & 89.36 \\
\hline 37 & Gabon & 30 & 35 & 6.45 & 6.97 & 5.80 & 60.22 & 2.72 & 37.40 & 51.79 & 59.46 \\
\hline 38 & U.K. & 86 & 81 & 8.89 & 9.10 & 30.90 & 88.58 & 8.08 & 83.60 & 88.15 & 89.91 \\
\hline 39 & Ghana & 33 & 43 & 5.19 & 5.79 & 2.40 & 60.38 & 5.35 & 67.50 & 50.64 & 55.67 \\
\hline 40 & Guinea & 19 & 27 & 3.64 & 4.14 & 2.20 & 41.66 & 2.02 & 31.40 & 40.45 & 46.82 \\
\hline 41 & Gambia & 25 & 26 & 4.20 & 4.52 & 1.80 & 50.30 & 4.39 & 29.10 & 51.12 & 54.92 \\
\hline 42 & Greece & 44 & 44 & 8.55 & 8.66 & 22.80 & 78.27 & 8.13 & 72.30 & 80.21 & 83.44 \\
\hline 43 & Guatemala & 26 & 28 & 5.78 & 6.40 & 5.20 & 61.69 & 6.07 & 59.20 & 56.59 & 57.71 \\
\hline 44 & Guyana & 25 & 34 & 6.20 & 6.38 & 3.80 & 60.00 & 6.15 & 62.50 & 49.78 & 59.99 \\
\hline 45 & Honduras & 25 & 30 & 5.90 & 6.25 & 2.80 & 60.65 & 6.25 & 59.20 & 57.05 & 60.57 \\
\hline 46 & Haiti & 18 & 20 & 4.58 & 4.93 & 1.60 & 43.15 & 4.19 & 40.20 & 34.53 & 38.47 \\
\hline 47 & Hungary & 52 & 48 & 8.09 & 8.36 & 16.10 & 76.88 & 7.53 & 67.20 & 86.30 & 87.02 \\
\hline 48 & Indonesia & 24 & 37 & 6.38 & 6.89 & 3.70 & 62.28 & 6.41 & 69.70 & 54.53 & 57.96 \\
\hline 49 & India & 33 & 40 & 5.46 & 6.24 & 3.40 & 53.92 & 7.68 & 78.10 & 47.98 & 50.87 \\
\hline 50 & Ireland & 74 & 73 & 9.02 & 9.23 & 34.10 & 87.94 & 9.01 & 91.50 & 89.89 & 95.20 \\
\hline
\end{tabular}




\begin{tabular}{|c|c|c|c|c|c|c|c|c|c|c|c|}
\hline 51 & Iceland & 96 & 78 & 8.87 & 9.21 & 34.90 & 88.45 & 9.71 & 95.00 & 71.77 & 81.39 \\
\hline 52 & Israel & 59 & 64 & 8.72 & 8.99 & 22.30 & 75.32 & 7.28 & 78.50 & 75.13 & 80.79 \\
\hline 53 & Italy & 49 & 47 & 8.62 & 8.87 & 28.40 & 82.49 & 7.73 & 79.80 & 81.77 & 83.57 \\
\hline 54 & Jamaica & 37 & 39 & 7.14 & 7.30 & 4.20 & 71.94 & 7.34 & 73.90 & 62.05 & 66.57 \\
\hline 55 & Jordan & 53 & 48 & 7.36 & 7.42 & 4.80 & 65.44 & 3.92 & 39.60 & 69.18 & 73.94 \\
\hline 56 & Japan & 76 & 72 & 8.77 & 9.03 & 30.70 & 86.54 & 8.15 & 79.90 & 65.61 & 68.81 \\
\hline 57 & Kenya & 22 & 26 & 4.94 & 5.55 & 1.20 & 53.72 & 5.08 & 53.30 & 42.55 & 45.80 \\
\hline 58 & Cambodia & 21 & 21 & 4.95 & 5.63 & 2.20 & 54.29 & 4.77 & 42.70 & 49.02 & 54.22 \\
\hline 59 & South_Korea & 51 & 53 & 8.67 & 9.01 & 20.40 & 80.92 & 7.88 & 79.20 & 61.36 & 66.05 \\
\hline 60 & Kuwait & 48 & 41 & 7.87 & 8.00 & 22.80 & 71.84 & 3.09 & 38.50 & 67.03 & 72.18 \\
\hline 61 & Lebanon & 36 & 28 & 7.31 & 7.63 & 5.30 & 64.43 & 5.82 & 48.60 & 67.36 & 74.20 \\
\hline 62 & Lesotho & 32 & 39 & 4.40 & 4.97 & 3.00 & 52.39 & 6.48 & 65.90 & 36.96 & 48.77 \\
\hline 63 & Luxembourg & 86 & 81 & 8.77 & 8.98 & 55.60 & 91.00 & 9.10 & 88.10 & 83.89 & 89.59 \\
\hline 64 & Morocco & 32 & 37 & 5.81 & 6.47 & 4.30 & 61.93 & 3.90 & 47.70 & 56.51 & 64.33 \\
\hline 65 & Moldova & 32 & 30 & 6.56 & 6.99 & 2.10 & 64.74 & 6.50 & 60.10 & 58.36 & 61.70 \\
\hline 66 & Madagascar & 31 & 26 & 4.83 & 5.12 & 0.90 & 45.91 & 5.82 & 50.70 & 39.25 & 42.98 \\
\hline 67 & Mexico & 33 & 30 & 7.31 & 7.62 & 10.10 & 70.03 & 6.67 & 64.70 & 57.99 & 61.61 \\
\hline 68 & Mali & 28 & 32 & 3.63 & 4.42 & 1.00 & 46.24 & 5.99 & 57.00 & 44.06 & 46.72 \\
\hline 69 & Malta & 64 & 55 & 8.08 & 8.56 & 19.00 & 84.60 & 8.39 & 83.90 & 76.39 & 78.24 \\
\hline 70 & Myanmar & 19 & 28 & 4.84 & 5.56 & 1.60 & 49.84 & 1.77 & 42.00 & 32.04 & 38.40 \\
\hline 71 & Montenegro & 28 & 45 & 7.62 & 8.07 & 2.70 & 68.17 & 6.57 & 57.20 & 56.97 & 66.92 \\
\hline 72 & Mongolia & 28 & 38 & 6.61 & 7.35 & 2.20 & 62.81 & 6.60 & 66.20 & 46.41 & 55.63 \\
\hline 73 & Mauritania & 31 & 27 & 4.75 & 5.13 & 2.00 & 46.08 & 3.12 & 39.60 & 43.65 & 52.55 \\
\hline 74 & Mauritius & 51 & 54 & 7.20 & 7.81 & 13.20 & 73.24 & 8.04 & 82.80 & 60.47 & 66.81 \\
\hline 75 & Malawi & 27 & 31 & 3.87 & 4.76 & 0.60 & 53.44 & 4.97 & 55.50 & 40.16 & 46.09 \\
\hline 76 & Malaysia & 50 & 49 & 7.36 & 7.89 & 10.40 & 70.08 & 5.98 & 65.40 & 79.14 & 81.07 \\
\hline 77 & Niger & 23 & 35 & 2.93 & 3.53 & 0.80 & 41.63 & 3.54 & 39.60 & 41.05 & 50.86 \\
\hline 78 & Nigeria & 22 & 28 & 4.77 & 5.27 & 1.00 & 46.49 & 3.52 & 45.00 & 48.17 & 52.53 \\
\hline 79 & Nicaragua & 26 & 26 & 6.01 & 6.45 & 2.40 & 63.04 & 5.68 & 48.10 & 51.57 & 53.56 \\
\hline 80 & Netherlands & 87 & 83 & 8.99 & 9.24 & 30.60 & 88.66 & 9.66 & 88.00 & 93.78 & 95.24 \\
\hline 81 & Norway & 88 & 85 & 9.34 & 9.49 & 42.40 & 88.70 & 9.55 & 99.30 & 85.24 & 86.83 \\
\hline 82 & Nepal & 25 & 29 & 4.86 & 5.58 & 1.50 & 57.41 & 3.42 & 48.60 & 34.44 & 36.70 \\
\hline 83 & New_Zealand & 96 & 90 & 8.91 & 9.15 & 24.20 & 88.46 & 9.01 & 92.60 & 78.48 & 80.12 \\
\hline 84 & Pakistan & 22 & 32 & 5.05 & 5.50 & 2.40 & 49.13 & 3.92 & 43.30 & 48.64 & 51.16 \\
\hline 85 & Panama & 31 & 38 & 7.43 & 7.88 & 7.10 & 73.02 & 7.35 & 71.30 & 65.63 & 67.56 \\
\hline 86 & Peru & 33 & 35 & 6.96 & 7.40 & 6.10 & 70.10 & 6.11 & 66.50 & 62.50 & 65.24 \\
\hline 87 & Philippines & 25 & 35 & 6.48 & 6.82 & 5.10 & 65.93 & 6.48 & 69.40 & 55.98 & 59.19 \\
\hline 88 & Poland & 37 & 62 & 8.08 & 8.55 & 12.70 & 79.76 & 7.30 & 68.30 & 76.61 & 79.32 \\
\hline 89 & Portugal & 66 & 62 & 7.97 & 8.43 & 18.60 & 83.88 & 8.16 & 78.60 & 83.54 & 88.21 \\
\hline
\end{tabular}




\begin{tabular}{|c|c|c|c|c|c|c|c|c|c|c|c|}
\hline 90 & Paraguay & 26 & 30 & 6.49 & 6.93 & 4.90 & 67.45 & 6.16 & 62.70 & 56.32 & 59.39 \\
\hline 91 & Romania & 31 & 48 & 7.66 & 8.02 & 8.40 & 72.24 & 7.06 & 66.20 & 64.99 & 73.36 \\
\hline 92 & Rwanda & 25 & 54 & 4.24 & 4.98 & 1.30 & 51.91 & 3.82 & 30.70 & 34.22 & 43.83 \\
\hline 93 & Saudi_Arabia & 33 & 46 & 7.73 & 8.47 & 12.90 & 66.31 & 1.92 & 19.30 & 66.57 & 69.75 \\
\hline 94 & Senegal & 33 & 45 & 4.25 & 4.94 & 1.70 & 55.65 & 5.37 & 62.10 & 51.75 & 54.59 \\
\hline 95 & Singapore & 94 & 84 & 8.73 & 9.25 & 29.90 & 82.19 & 5.89 & 63.80 & 87.04 & 91.52 \\
\hline 96 & Sierra_Leone & 22 & 30 & 3.57 & 4.20 & 0.90 & 44.22 & 3.57 & 45.50 & 36.81 & 48.29 \\
\hline 97 & El_Salvador & 40 & 36 & 6.57 & 6.80 & 5.10 & 66.37 & 6.22 & 66.40 & 59.25 & 64.02 \\
\hline 98 & Sweden & 92 & 88 & 8.95 & 9.13 & 29.80 & 88.80 & 9.88 & 93.90 & 89.13 & 91.73 \\
\hline 99 & Swaziland & 25 & 43 & 5.08 & 5.41 & 5.50 & 51.76 & 2.93 & 30.30 & 47.23 & 51.92 \\
\hline 100 & Syr_Arab_Rep & 29 & 13 & 6.44 & 5.36 & 3.40 & 52.10 & 2.36 & 14.30 & 45.17 & 50.02 \\
\hline 101 & Chad & 20 & 20 & 3.06 & 3.96 & 1.80 & 36.38 & 1.65 & 15.00 & 39.14 & 41.70 \\
\hline 102 & Togo & 24 & 32 & 4.43 & 4.87 & 1.70 & 49.03 & 1.75 & 33.20 & 47.25 & 54.25 \\
\hline 103 & Thailand & 36 & 35 & 6.87 & 7.40 & 8.30 & 67.44 & 5.67 & 49.20 & 62.95 & 71.71 \\
\hline 104 & Trinid \& Tobago & 32 & 35 & 7.60 & 7.80 & 12.90 & 69.00 & 7.18 & 71.00 & 59.84 & 65.62 \\
\hline 105 & Tunisia & 46 & 41 & 6.95 & 7.25 & 7.60 & 68.01 & 3.06 & 64.00 & 58.22 & 60.63 \\
\hline 106 & Turkey & 38 & 41 & 6.97 & 7.67 & 7.90 & 67.83 & 5.70 & 50.40 & 65.92 & 69.88 \\
\hline 107 & Tanzania & 29 & 32 & 4.57 & 5.31 & 0.70 & 49.99 & 5.18 & 57.60 & 34.91 & 37.42 \\
\hline 108 & Uganda & 27 & 25 & 4.42 & 4.93 & 1.70 & 50.69 & 5.14 & 52.60 & 42.80 & 45.69 \\
\hline 109 & Uruguay & 64 & 71 & 7.60 & 7.95 & 16.00 & 80.12 & 7.96 & 81.70 & 66.74 & 68.14 \\
\hline 110 & U.S.A. & 73 & 74 & 9.01 & 9.20 & 42.00 & 84.62 & 8.22 & 79.80 & 78.47 & 81.15 \\
\hline 111 & Venezuela_RB & 23 & 17 & 7.28 & 7.67 & 6.50 & 63.46 & 5.42 & 46.80 & 48.92 & 55.45 \\
\hline 112 & Vietnam & 26 & 33 & 6.25 & 6.83 & 3.00 & 63.47 & 2.75 & 33.80 & 42.59 & 54.98 \\
\hline 113 & Yemen_Rep. & 26 & 14 & 4.77 & 4.82 & 0.80 & 41.76 & 2.98 & 20.70 & 42.64 & 46.66 \\
\hline 114 & South_Africa & 46 & 45 & 6.12 & 6.66 & 12.10 & 67.61 & 7.91 & 74.10 & 64.93 & 67.54 \\
\hline 115 & Congo_D_Rep. & 20 & 21 & 3.70 & 4.35 & 0.80 & 46.23 & 2.76 & 19.30 & 24.95 & 42.31 \\
\hline 116 & Zambia & 26 & 38 & 4.92 & 5.79 & 0.90 & 50.00 & 5.25 & 59.90 & 46.41 & 54.04 \\
\hline
\end{tabular}

Table-A-2. Corruption Perception Index, Human Development Index, Per Capita Income, Social Progress Index, Democracy Index and Overall Globalization Index in the Countries under Study

Sources: Wikipedia for Corruption Perception, Human Development, Per-capita Income (in Int\$1000), Social Progress and Democracy Indices. For Overall Globalization Index, GI(Max) and GI(Min) based on AEMC principle, see Tables 3 and 4 below.

\begin{tabular}{clccccccccc}
\hline SL & Country & Year-H & E1 & E2 & S1 & S2 & S3 & P & KOF & AEMC \\
\hline 1 & Albania & 2009 & 56.57 & 73.00 & 52.55 & 73.90 & 2.42 & 80.69 & 61.60 & 61.61 \\
\hline 2 & Argentina & 2008 & 45.92 & 39.11 & 43.30 & 71.50 & 41.47 & 92.07 & 59.95 & 59.19 \\
\hline 3 & Australia & 2007 & 74.79 & 81.24 & 73.40 & 87.55 & 94.03 & 89.71 & 83.80 & 84.03 \\
\hline 4 & Austria & 2007 & 89.34 & 86.56 & 87.06 & 92.06 & 95.54 & 96.86 & 91.87 & 93.95 \\
\hline 5 & Azerbaijan & 2007 & 67.38 & 63.70 & 37.92 & 77.61 & 34.96 & 54.01 & 57.02 & 54.69 \\
\hline 6 & Burundi & 2014 & 23.53 & 33.37 & 21.02 & 37.22 & 3.10 & 62.17 & 35.04 & 34.79 \\
\hline
\end{tabular}




\begin{tabular}{|c|c|c|c|c|c|c|c|c|c|c|}
\hline 7 & Belgium & 2007 & 96.71 & 82.81 & 81.94 & 96.39 & 91.22 & 97.67 & 92.41 & 93.75 \\
\hline 8 & Benin & 2014 & 53.79 & 42.92 & 28.55 & 39.46 & 2.48 & 75.17 & 46.67 & 48.99 \\
\hline 9 & Burkina_Faso & 2014 & 59.67 & 46.84 & 19.43 & 44.62 & 2.17 & 76.88 & 48.69 & 49.12 \\
\hline 10 & Bulgaria & 2013 & 80.04 & 72.93 & 51.55 & 77.71 & 85.30 & 84.96 & 76.98 & 76.34 \\
\hline 11 & Bolivia & 2006 & 62.03 & 59.79 & 39.52 & 51.01 & 3.78 & 75.69 & 54.42 & 56.38 \\
\hline 12 & Brazil & 2014 & 51.77 & 52.82 & 24.46 & 70.50 & 39.58 & 94.30 & 61.40 & 58.16 \\
\hline 13 & Bhutan & 2014 & 60.64 & 56.77 & 46.83 & 45.54 & 6.87 & 38.85 & 43.58 & 47.07 \\
\hline 14 & Botswana & 2008 & 77.58 & 59.64 & 59.54 & 57.17 & 5.88 & 59.28 & 55.50 & 60.64 \\
\hline 15 & C._Afr_Rep & 2014 & 49.56 & 28.29 & 13.44 & 40.71 & 2.24 & 58.39 & 36.34 & 37.27 \\
\hline 16 & Canada & 2007 & 76.20 & 82.03 & 80.78 & 94.74 & 96.09 & 92.91 & 87.15 & 87.51 \\
\hline 17 & Switzerland & 2014 & 95.02 & 70.51 & 91.77 & 87.57 & 94.47 & 93.40 & 88.79 & 93.18 \\
\hline 18 & Chile & 2007 & 82.68 & 87.08 & 41.25 & 77.69 & 41.18 & 87.67 & 74.31 & 72.77 \\
\hline 19 & China & 2014 & 43.49 & 62.19 & 18.71 & 65.65 & 78.37 & 84.26 & 62.02 & 56.85 \\
\hline 20 & Cote_d'Ivoire & 2007 & 63.35 & 40.17 & 41.85 & 52.15 & 2.85 & 70.72 & 49.83 & 53.08 \\
\hline 21 & Cameroon & 2014 & 44.96 & 38.31 & 16.91 & 52.02 & 2.24 & 73.16 & 44.20 & 42.75 \\
\hline 22 & Congo_Rep. & 2014 & 96.24 & 41.58 & 35.45 & 43.93 & 1.25 & 63.67 & 51.83 & 57.31 \\
\hline 23 & Colombia & 2013 & 58.32 & 57.38 & 33.46 & 69.69 & 38.12 & 79.65 & 60.15 & 58.23 \\
\hline 24 & Costa_Rica & 2007 & 64.79 & 73.30 & 60.37 & 78.75 & 45.65 & 58.63 & 63.66 & 63.45 \\
\hline 25 & Cyprus & 2008 & 93.50 & 84.06 & 88.10 & 95.69 & 93.84 & 78.36 & 87.32 & 89.36 \\
\hline 26 & Germany & 2007 & 81.36 & 84.49 & 76.35 & 87.52 & 92.57 & 92.43 & 86.48 & 87.44 \\
\hline 27 & Denmark & 2007 & 87.80 & 89.09 & 83.64 & 89.59 & 93.06 & 93.75 & 90.01 & 91.90 \\
\hline 28 & Domin_Rep & 2014 & 64.15 & 59.56 & 53.70 & 64.97 & 79.14 & 73.31 & 66.45 & 67.20 \\
\hline 29 & Algeria & 2006 & 55.36 & 52.55 & 32.39 & 64.92 & 1.93 & 80.65 & 54.00 & 53.32 \\
\hline 30 & Ecuador & 2006 & 55.97 & 46.00 & 36.82 & 65.37 & 38.22 & 79.01 & 57.39 & 56.77 \\
\hline 31 & Egypt & 2013 & 42.96 & 48.68 & 27.64 & 66.78 & 77.77 & 93.01 & 63.10 & 59.62 \\
\hline 32 & Spain & 2007 & 78.33 & 81.36 & 74.93 & 87.72 & 90.22 & 95.93 & 85.92 & 86.71 \\
\hline 33 & Ethiopia & 2014 & 24.93 & 28.39 & 19.32 & 33.17 & 2.85 & 82.51 & 39.33 & 39.87 \\
\hline 34 & Finland & 2007 & 85.16 & 87.39 & 72.07 & 90.60 & 91.67 & 91.64 & 87.22 & 87.36 \\
\hline 35 & Fiji & 2014 & 74.43 & 25.70 & 56.98 & 57.20 & 43.56 & 69.68 & 57.56 & 61.30 \\
\hline 36 & France & 2007 & 76.99 & 87.19 & 80.56 & 88.36 & 91.79 & 97.96 & 88.23 & 89.36 \\
\hline 37 & Gabon & 2014 & 75.55 & 42.75 & 52.22 & 63.44 & 2.36 & 72.30 & 55.96 & 59.46 \\
\hline 38 & U.K. & 2006 & 81.91 & 89.75 & 79.57 & 90.54 & 93.30 & 94.90 & 89.06 & 89.91 \\
\hline 39 & Ghana & 2014 & 62.30 & 54.48 & 27.85 & 45.77 & 3.96 & 85.72 & 54.17 & 55.67 \\
\hline 40 & Guinea & 2014 & 57.21 & 31.29 & 21.72 & 41.38 & 2.73 & 76.19 & 44.40 & 46.82 \\
\hline 41 & Gambia & 2006 & 70.76 & 49.68 & 45.63 & 57.79 & 6.31 & 61.86 & 51.78 & 54.92 \\
\hline 42 & Greece & 2007 & 68.15 & 83.53 & 76.51 & 83.41 & 85.44 & 92.38 & 82.59 & 83.44 \\
\hline 43 & Guatemala & 2014 & 48.00 & 74.96 & 26.23 & 57.23 & 42.95 & 83.01 & 60.42 & 57.71 \\
\hline 44 & Guyana & 2006 & 80.52 & 62.07 & 56.43 & 55.51 & 44.10 & 43.34 & 56.44 & 59.99 \\
\hline 45 & Honduras & 2014 & 74.61 & 71.19 & 28.45 & 58.46 & 39.51 & 71.84 & 61.42 & 60.57 \\
\hline
\end{tabular}




\begin{tabular}{|c|c|c|c|c|c|c|c|c|c|c|}
\hline 46 & Haiti & 2010 & 34.21 & 62.93 & 28.71 & 50.84 & 1.00 & 45.88 & 39.36 & 38.47 \\
\hline 47 & Hungary & 2009 & 92.14 & 85.86 & 65.93 & 89.31 & 89.62 & 91.47 & 86.99 & 87.02 \\
\hline 48 & Indo & 2014 & 56.25 & 71.79 & 20.40 & 49.92 & 33.89 & 86.83 & 59.65 & 57.96 \\
\hline 49 & India & 2014 & 43.78 & 44.93 & 14.10 & 45.12 & 32.98 & 91.23 & 52.38 & 50.87 \\
\hline 50 & Ireland & 2014 & 99.52 & 89.78 & 89.37 & 91.72 & 91.88 & 90.47 & 92.15 & 95.20 \\
\hline 51 & Iceland & 2008 & 89.32 & 64.89 & 81.47 & 80.36 & 91.88 & 70.11 & 77.86 & 81.39 \\
\hline 52 & Israel & 2010 & 71.59 & 83.51 & 75.06 & 67.25 & 90.37 & 80.29 & 78.15 & 80.79 \\
\hline 53 & Italy & 2007 & 68.17 & 83.24 & 70.46 & 78.72 & 86.52 & 97.92 & 82.85 & 83.57 \\
\hline 54 & Jamaica & 2007 & 80.64 & 70.00 & 63.13 & 69.52 & 7.11 & 68.56 & 62.72 & 66.57 \\
\hline 55 & Jordan & 2006 & 79.36 & 59.47 & 67.97 & 71.54 & 41.11 & 84.27 & 70.31 & 73.94 \\
\hline 56 & Japan & 2014 & 50.41 & 76.54 & 43.39 & 75.59 & 87.91 & 88.10 & 72.26 & 68.81 \\
\hline 57 & Kenya & 2007 & 27.19 & 46.79 & 29.61 & 46.02 & 3.72 & 82.92 & 46.46 & 45.80 \\
\hline 58 & Cambodia & 2014 & 85.86 & 50.76 & 29.52 & 48.48 & 1.31 & 62.36 & 50.69 & 54.22 \\
\hline 59 & South_Korea & 2014 & 62.52 & 63.76 & 43.81 & 73.55 & 42.42 & 89.58 & 67.03 & 66.05 \\
\hline 60 & Kuwait & 2008 & 61.31 & 75.01 & 78.96 & 76.28 & 90.41 & 59.54 & 70.76 & 72.18 \\
\hline 61 & Lebanon & 2006 & 86.92 & 62.30 & 70.38 & 81.04 & 43.26 & 74.55 & 70.50 & 74.20 \\
\hline 62 & Lesotho & 2014 & 80.48 & 41.22 & 25.58 & 48.74 & 6.87 & 54.09 & 45.94 & 48.77 \\
\hline 63 & Luxembo & 2007 & 100.00 & 8 & 96.09 & 97.51 & 48.25 & 80.06 & 85.62 & 89.59 \\
\hline 64 & Morocco & 2014 & 60.71 & 53.68 & 45.87 & 83.86 & 37.71 & 89.50 & 65.95 & 64.33 \\
\hline 65 & Moldova & 2007 & 67.96 & 69.67 & 44.90 & 84.17 & 39.27 & 67.22 & 64.04 & 61.70 \\
\hline 66 & Madagascar & 2014 & 62.47 & 36.71 & 11.21 & 48.02 & 2.73 & 65.10 & 42.90 & 42.98 \\
\hline 67 & Mexico & 2014 & 63.45 & 68.45 & 44.30 & 68.92 & 40.12 & 71.72 & 62.29 & 61.61 \\
\hline 68 & Mali & 2014 & 50.97 & 41.67 & 22.46 & 44.10 & 1.12 & 75.98 & 46.07 & 46.72 \\
\hline 69 & Malta & 2009 & 99.76 & 87.06 & 8 & 4 & 49.74 & 52 & 76.16 & 78.24 \\
\hline 70 & Myanmar & 2014 & 56.93 & 56.33 & 11.89 & 42.07 & 1.00 & 44.74 & 03 & 38.40 \\
\hline 71 & Montenegro & 2010 & 81.65 & 79.55 & 72.69 & 94.41 & 5.08 & 56.33 & 65.48 & 66.92 \\
\hline 72 & Mongolia & 2014 & 84.88 & 65.73 & 16.76 & 59.40 & 1.43 & 71.89 & 56.91 & 55.63 \\
\hline 73 & Mauritania & 2014 & 79.30 & 58.16 & 19.77 & 51.82 & 1.37 & 66.99 & 51.45 & 52.55 \\
\hline 74 & Mauritius & 2014 & 91.12 & 84.89 & 58.78 & 82.06 & 42.61 & 45.32 & 66.61 & 66.81 \\
\hline 75 & Malawi & 2013 & 49.90 & 52.47 & 26.25 & 41.95 & 6.99 & 64.35 & 45.40 & 46.09 \\
\hline 76 & Mala & 2010 & 85 & 69 & 1 & 75.92 & 87.52 & 83.17 & 79.12 & 81.07 \\
\hline 77 & Niger & 2014 & 54.67 & 50.44 & 32.41 & 35.30 & 1.74 & 74.33 & 47.92 & 50.86 \\
\hline 78 & Nigeria & 2009 & 65.10 & 47.51 & 12.39 & 52.93 & 3.47 & 89.37 & 54.36 & 52.53 \\
\hline 79 & Nicaragua & 2012 & 61.15 & 61.69 & 34.97 & 56.57 & 40.24 & 57.38 & 53.99 & 53.56 \\
\hline 80 & Netherlands & 2014 & 97.64 & 88.48 & 85.98 & 93.26 & 92.75 & 95.41 & 92.84 & 95.24 \\
\hline 81 & Norway & 2013 & 80.32 & 72.93 & 81.74 & 85.52 & 91.68 & 92.27 & 84.48 & 86.83 \\
\hline 82 & Nepal & 2013 & 13.26 & 39.95 & 24.97 & 44.85 & 2.79 & 70.69 & 38.18 & 36.70 \\
\hline 83 & New_Zealand & 2008 & 76.62 & 90.04 & 79.32 & 91.46 & 50.44 & 80.05 & 79.17 & 80.12 \\
\hline 84 & Pakistan & 2007 & 40.85 & 43.25 & 23.40 & 44.12 & 32.38 & 87.55 & 51.83 & 51.16 \\
\hline
\end{tabular}




\begin{tabular}{|c|c|c|c|c|c|c|c|c|c|c|}
\hline 85 & Panama & 2009 & 89.59 & 71.32 & 50.84 & 81.17 & 47.74 & 60.74 & 67.70 & 67.56 \\
\hline 86 & Peru & 2011 & 69.02 & 82.53 & 32.33 & 58.27 & 36.87 & 84.74 & 66.14 & 65.24 \\
\hline 87 & Philippines & 2006 & 65.22 & 52.73 & 30.26 & 49.70 & 39.96 & 81.96 & 58.39 & 59.19 \\
\hline 88 & Poland & 2014 & 77.73 & 76.38 & 57.40 & 92.23 & 89.22 & 88.82 & 81.32 & 79.32 \\
\hline 89 & Portugal & 2007 & 82.71 & 87.10 & 76.48 & 91.10 & 88.73 & 93.85 & 87.61 & 88.21 \\
\hline 90 & Paraguay & 2012 & 62.44 & 56.59 & 36.33 & 65.09 & 39.86 & 77.61 & 60.13 & 59.39 \\
\hline 91 & Romania & 2014 & 60.67 & 83.22 & 48.07 & 82.02 & 82.39 & 89.82 & 76.51 & 73.36 \\
\hline 92 & Rwanda & 2014 & 34.81 & 63.91 & 17.27 & 39.87 & 7.05 & 71.53 & 45.56 & 43.83 \\
\hline 93 & Saudi_Arabia & 2009 & 62.95 & 76.19 & 69.00 & 71.18 & 83.25 & 60.43 & 68.43 & 69.75 \\
\hline 94 & Senegal & 2012 & 57.58 & 47.32 & 29.33 & 58.91 & 3.53 & 87.90 & 54.64 & 54.59 \\
\hline 95 & Singapore & 2009 & 99.01 & 95.35 & 92.18 & 88.25 & 96.12 & 71.77 & 88.27 & 91.52 \\
\hline 96 & Sierra_Leone & 2011 & 69.70 & 46.89 & 19.84 & 38.92 & 3.16 & 65.10 & 45.90 & 48.29 \\
\hline 97 & El_Salvador & 2007 & 61.06 & 72.79 & 49.35 & 64.68 & 40.80 & 75.40 & 63.79 & 64.02 \\
\hline 98 & Sweden & 2007 & 88.33 & 86.26 & 80.84 & 84.38 & 94.73 & 96.03 & 89.41 & 91.73 \\
\hline 99 & Swaziland & 2014 & 77.83 & 43.61 & 59.31 & 60.20 & 6.37 & 36.55 & 47.48 & 51.92 \\
\hline 100 & Syr_Arab_Rep & 2011 & 53.48 & 55.43 & 51.94 & 65.49 & 1.00 & 52.73 & 48.93 & 50.02 \\
\hline 101 & Chad & 2006 & 55.49 & 27.21 & 23.94 & 32.35 & 2.91 & 60.04 & 38.37 & 41.70 \\
\hline 102 & Togo & 2014 & 78.62 & 46.54 & 25.04 & 57.99 & 3.72 & 73.38 & 53.70 & 54.25 \\
\hline 103 & Thailand & 2012 & 83.87 & 59.54 & 42.90 & 72.93 & 80.93 & 81.22 & 72.06 & 71.71 \\
\hline 104 & Trinid \& Tobago & 2012 & 86.13 & 68.86 & 58.65 & 67.24 & 41.73 & 53.54 & 63.09 & 65.62 \\
\hline 105 & Tunisia & 2008 & 70.83 & 48.71 & 41.68 & 76.78 & 2.67 & 86.29 & 60.45 & 60.63 \\
\hline 106 & Turkey & 2014 & 51.09 & 66.13 & 50.76 & 72.49 & 81.59 & 91.88 & 71.33 & 69.88 \\
\hline 107 & Tanzania & 2007 & 35.61 & 53.20 & 16.78 & 31.93 & 3.04 & 55.74 & 37.71 & 37.42 \\
\hline 108 & Uganda & 2013 & 44.01 & 58.02 & 21.59 & 37.01 & 4.52 & 70.23 & 45.48 & 45.69 \\
\hline 109 & Uruguay & 2008 & 65.66 & 68.87 & 51.35 & 65.92 & 42.10 & 85.45 & 67.23 & 68.14 \\
\hline 110 & U.S.A. & 2007 & 65.17 & 85.34 & 67.13 & 82.45 & 91.90 & 92.10 & 81.80 & 81.15 \\
\hline 111 & Venezuela_RB & 2006 & 62.32 & 47.83 & 38.48 & 68.43 & 41.65 & 65.68 & 56.17 & 55.45 \\
\hline 112 & Vietnam & 2014 & 80.26 & 49.28 & 16.43 & 63.78 & 31.92 & 71.13 & 56.69 & 54.98 \\
\hline 113 & Yemen_Rep. & 2008 & 53.37 & 63.83 & 23.57 & 41.91 & 1.68 & 62.24 & 46.51 & 46.66 \\
\hline 114 & South_Africa & 2014 & 72.64 & 65.18 & 41.53 & 61.39 & 41.93 & 88.04 & 66.72 & 67.54 \\
\hline 115 & Congo_D_Rep. & 2013 & 69.13 & 37.26 & 6.23 & 43.38 & 1.00 & 62.03 & 41.67 & 42.31 \\
\hline 116 & Zambia & 2007 & 64.24 & 63.96 & 27.92 & 45.69 & 4.09 & 73.93 & 52.96 & 54.04 \\
\hline
\end{tabular}

$\mathrm{E} 1, \mathrm{E} 2, \mathrm{~S} 1, \mathrm{~S} 2, \mathrm{~S} 3, \mathrm{P}$ and KOF are for the Year-H when the overall index AEMC attained maximum (Gmax) during 2006-2014. AEMC Indices are computed by the author.

Table-A-3. Economic, Social and Political Dimensions and Overall Indices of Globalization in Different Countries [Source: http://globalization.kof.ethz.ch] 


\begin{tabular}{|c|c|c|c|c|c|c|c|c|c|c|}
\hline SL & Country & Year-L & E1 & E2 & S1 & S2 & S3 & $\mathbf{P}$ & KOF & AEMC \\
\hline 1 & Albania & 2006 & 35.89 & 58.68 & 52.56 & 69.39 & 2.24 & 67.63 & 51.18 & 50.86 \\
\hline 2 & Argentina & 2012 & 41.13 & 30.68 & 43.54 & 72.69 & 40.54 & 92.83 & 57.89 & 57.09 \\
\hline 3 & Australia & 2013 & 68.41 & 78.01 & 73.79 & 85.80 & 92.90 & 90.42 & 81.97 & 82.24 \\
\hline 4 & Austria & 2013 & 85.52 & 76.50 & 86.51 & 91.31 & 95.46 & 96.36 & 89.09 & 91.36 \\
\hline 5 & Azerbaijan & 2009 & 59.96 & 57.99 & 38.90 & 78.95 & 34.51 & 55.51 & 55.35 & 52.78 \\
\hline 6 & Burundi & 2006 & 24.06 & 35.17 & 16.96 & 35.39 & 4.15 & 36.97 & 27.89 & 26.92 \\
\hline 7 & Belgium & 2013 & 95.51 & 73.19 & 84.04 & 96.99 & 91.01 & 96.51 & 90.70 & 92.32 \\
\hline 8 & Benin & 2006 & 28.32 & 40.26 & 28.88 & 35.40 & 2.54 & 71.83 & 40.22 & 41.61 \\
\hline 9 & Burkina_Faso & 2006 & 16.39 & 50.78 & 32.95 & 36.90 & 3.90 & 71.57 & 40.68 & 41.27 \\
\hline 10 & Bulgaria & 2010 & 71.76 & 74.41 & 50.21 & 82.83 & 40.81 & 83.13 & 70.59 & 69.36 \\
\hline 11 & Bolivia & 2011 & 56.44 & 50.56 & 37.79 & 58.44 & 2.91 & 76.81 & 52.76 & 53.62 \\
\hline 12 & Brazil & 2008 & 48.27 & 53.34 & 20.26 & 68.50 & 38.23 & 92.27 & 59.38 & 55.59 \\
\hline 13 & Bhutan & 2007 & 34.97 & 56.40 & 46.37 & 41.28 & 5.32 & 21.18 & 33.12 & 35.44 \\
\hline 14 & Botswana & 2012 & 60.07 & 53.50 & 56.45 & 55.16 & 4.95 & 39.77 & 45.21 & 49.05 \\
\hline 15 & C._Afr_Rep & 2007 & 40.14 & 22.02 & 15.27 & 32.43 & 2.24 & 57.98 & 32.80 & 34.45 \\
\hline 16 & Canada & 2013 & 74.03 & 77.68 & 81.23 & 92.24 & 94.97 & 92.94 & 85.60 & 86.39 \\
\hline 17 & Switzerland & 2011 & 94.70 & 60.22 & 91.35 & 89.06 & 94.96 & 92.44 & 86.84 & 91.37 \\
\hline 18 & Chile & 2013 & 77.71 & 75.92 & 38.21 & 76.16 & 40.69 & 88.74 & 71.11 & 69.54 \\
\hline 19 & China & 2012 & 41.21 & 56.27 & 16.75 & 65.54 & 78.02 & 84.80 & 60.42 & 55.12 \\
\hline 20 & Cote_d'Ivoire & 2013 & 56.86 & 36.44 & 29.24 & 53.69 & 2.61 & 74.19 & 47.92 & 48.82 \\
\hline 21 & Cameroon & 2010 & 35.79 & 41.44 & 16.83 & 51.95 & 2.73 & 70.25 & 42.67 & 40.16 \\
\hline 22 & Congo_Rep. & 2008 & 91.35 & 37.23 & 31.94 & 40.90 & 1.74 & 39.88 & 42.91 & 47.78 \\
\hline 23 & Colombia & 2008 & 54.98 & 42.87 & 30.73 & 70.80 & 38.22 & 78.48 & 56.48 & 54.44 \\
\hline 24 & Costa_Rica & 2013 & 62.90 & 66.25 & 55.31 & 81.31 & 45.89 & 59.43 & 62.05 & 61.03 \\
\hline 25 & Cyprus & 2006 & 91.53 & 84.62 & 86.55 & 95.34 & 47.57 & 59.05 & 76.11 & 78.44 \\
\hline 26 & Germany & 2013 & 75.94 & 73.34 & 79.32 & 85.40 & 92.01 & 91.93 & 83.41 & 85.16 \\
\hline 27 & Denmark & 2013 & 84.52 & 80.70 & 81.47 & 88.35 & 93.53 & 91.65 & 86.99 & 88.85 \\
\hline 28 & Domin_Rep & 2009 & 54.07 & 57.06 & 53.37 & 67.39 & 36.62 & 56.88 & 55.00 & 55.44 \\
\hline 29 & Algeria & 2007 & 49.62 & 47.76 & 33.94 & 64.81 & 2.05 & 48.49 & 43.47 & 42.36 \\
\hline 30 & Ecuador & 2014 & 40.55 & 36.53 & 34.14 & 62.25 & 38.21 & 80.97 & 52.78 & 51.64 \\
\hline 31 & Egypt & 2012 & 41.62 & 46.07 & 22.45 & 66.66 & 35.94 & 93.45 & 56.99 & 53.67 \\
\hline 32 & Spain & 2013 & 75.24 & 74.68 & 73.88 & 86.21 & 89.60 & 95.51 & 83.68 & 84.60 \\
\hline 33 & Ethiopia & 2011 & 28.98 & 21.94 & 10.54 & 29.29 & 2.17 & 81.88 & 36.82 & 37.47 \\
\hline 34 & Finland & 2009 & 77.81 & 86.19 & 72.26 & 88.86 & 91.36 & 90.25 & 85.08 & 85.04 \\
\hline 35 & Fiji & 2009 & 64.73 & 25.64 & 56.01 & 50.18 & 43.87 & 66.56 & 53.75 & 57.81 \\
\hline 36 & France & 2013 & 73.58 & 78.12 & 81.13 & 89.14 & 92.48 & 97.29 & 86.09 & 87.32 \\
\hline 37 & Gabon & 2011 & 75.77 & 31.78 & 51.97 & 61.25 & 2.36 & 51.11 & 47.92 & 51.79 \\
\hline 38 & U.K. & 2014 & 80.71 & 85.27 & 76.35 & 87.66 & 93.64 & 94.67 & 87.26 & 88.15 \\
\hline
\end{tabular}




\begin{tabular}{|c|c|c|c|c|c|c|c|c|c|c|}
\hline 39 & Ghana & 2008 & 36.37 & 51.83 & 35.82 & 43.80 & 4.52 & 83.98 & 49.19 & 50.64 \\
\hline 40 & Guinea & 2010 & 35.70 & 31.29 & 21.36 & 39.92 & 4.15 & 71.90 & 39.38 & 40.45 \\
\hline 41 & Gambia & 2009 & 50.86 & 50.47 & 45.99 & 61.95 & 5.38 & 64.80 & 50.18 & 51.12 \\
\hline 42 & Greece & 2012 & 61.28 & 77.37 & 75.14 & 84.24 & 84.42 & 91.33 & 79.82 & 80.21 \\
\hline 43 & Guatemala & 2010 & 46.46 & 68.40 & 27.08 & 56.03 & 43.98 & 82.47 & 58.89 & 56.59 \\
\hline 44 & Guyana & 2013 & 61.74 & 58.98 & 48.79 & 58.06 & 5.76 & 44.66 & 47.60 & 49.78 \\
\hline 45 & Honduras & 2010 & 63.36 & 65.10 & 30.16 & 60.23 & 39.72 & 70.29 & 58.38 & 57.05 \\
\hline 46 & Haiti & 2014 & 35.21 & 68.47 & 6.41 & 51.82 & 1.00 & 48.28 & 38.81 & 34.53 \\
\hline 47 & Hungary & 2011 & 91.22 & 81.45 & 66.67 & 89.18 & 90.33 & 90.93 & 86.05 & 86.30 \\
\hline 48 & Indonesia & 2008 & 49.64 & 69.02 & 17.85 & 47.95 & 33.79 & 84.05 & 56.64 & 54.53 \\
\hline 49 & India & 2006 & 35.28 & 43.76 & 13.64 & 46.46 & 32.53 & 89.37 & 50.22 & 47.98 \\
\hline 50 & Ireland & 2008 & 97.80 & 88.49 & 91.12 & 92.11 & 48.10 & 87.41 & 85.93 & 89.89 \\
\hline 51 & Iceland & 2013 & 89.48 & 59.80 & 80.56 & 78.37 & 50.11 & 54.09 & 67.32 & 71.77 \\
\hline 52 & Israel & 2011 & 69.88 & 76.98 & 75.38 & 66.87 & 90.37 & 65.01 & 72.46 & 75.13 \\
\hline 53 & Italy & 2013 & 64.98 & 75.44 & 70.42 & 78.44 & 88.21 & 97.52 & 80.94 & 81.77 \\
\hline 54 & Jamaica & 2014 & 73.94 & 51.72 & 57.00 & 67.13 & 6.93 & 72.58 & 58.43 & 62.05 \\
\hline 55 & Jordan & 2013 & 72.22 & 61.91 & 52.07 & 69.51 & 42.37 & 86.09 & 67.93 & 69.18 \\
\hline 56 & Japan & 2011 & 43.92 & 65.57 & 42.19 & 76.22 & 87.85 & 88.66 & 69.25 & 65.61 \\
\hline 57 & Kenya & 2012 & 25.69 & 44.87 & 19.21 & 48.47 & 3.59 & 82.94 & 45.16 & 42.55 \\
\hline 58 & Cambodia & 2011 & 70.40 & 50.86 & 26.14 & 44.44 & 2.17 & 59.93 & 46.83 & 49.02 \\
\hline 59 & South_Korea & 2006 & 54.55 & 65.58 & 39.06 & 76.10 & 41.38 & 83.59 & 63.92 & 61.36 \\
\hline 60 & Kuwait & 2013 & 53.45 & 65.47 & 70.68 & 73.63 & 89.69 & 60.31 & 66.44 & 67.03 \\
\hline 61 & Lebanon & 2011 & 77.07 & 56.80 & 70.26 & 90.02 & 45.95 & 60.76 & 65.70 & 67.36 \\
\hline 62 & Lesotho & 2006 & 59.43 & 37.57 & 24.70 & 45.45 & 6.68 & 33.39 & 35.69 & 36.96 \\
\hline 63 & Luxembourg & 2006 & 99.72 & 87.43 & 96.37 & 96.87 & 48.06 & 60.97 & 80.05 & 83.89 \\
\hline 64 & Morocco & 2006 & 49.22 & 40.66 & 35.46 & 67.40 & 37.20 & 87.73 & 57.63 & 56.51 \\
\hline 65 & Moldova & 2014 & 60.52 & 63.40 & 40.67 & 84.06 & 37.77 & 69.00 & 61.39 & 58.36 \\
\hline 66 & Madagascar & 2011 & 56.71 & 28.24 & 8.15 & 49.42 & 2.67 & 63.64 & 39.71 & 39.25 \\
\hline 67 & Mexico & 2008 & 55.23 & 60.32 & 42.67 & 70.30 & 41.09 & 70.95 & 59.27 & 57.99 \\
\hline 68 & Mali & 2007 & 44.08 & 41.64 & 20.96 & 36.32 & 2.17 & 73.60 & 43.06 & 44.06 \\
\hline 69 & Malta & 2006 & 97.19 & 87.13 & 83.62 & 96.07 & 50.17 & 47.77 & 74.50 & 76.39 \\
\hline 70 & Myanmar & 2009 & 47.20 & 49.84 & 9.82 & 27.94 & 1.00 & 36.00 & 31.86 & 32.04 \\
\hline 71 & Montenegro & 2006 & 52.52 & 76.75 & 73.23 & 94.86 & 6.25 & 46.57 & 57.31 & 56.97 \\
\hline 72 & Mongolia & 2006 & 54.54 & 60.02 & 19.54 & 57.15 & 2.05 & 65.31 & 48.72 & 46.41 \\
\hline 73 & Mauritania & 2006 & 72.75 & 40.60 & 25.64 & 43.51 & 1.37 & 45.02 & 40.79 & 43.65 \\
\hline 74 & Mauritius & 2006 & 57.62 & 70.87 & 59.49 & 85.06 & 40.57 & 57.79 & 61.85 & 60.47 \\
\hline 75 & Malawi & 2009 & 32.32 & 44.30 & 27.07 & 39.17 & 6.74 & 61.73 & 39.76 & 40.16 \\
\hline 76 & Malaysia & 2014 & 88.91 & 66.95 & 57.96 & 77.28 & 87.65 & 83.69 & 78.14 & 79.14 \\
\hline
\end{tabular}




\begin{tabular}{|c|c|c|c|c|c|c|c|c|c|c|}
\hline 77 & Niger & 2007 & 24.17 & 37.19 & 32.59 & 30.52 & 1.68 & 71.94 & 38.88 & 41.05 \\
\hline 78 & Nigeria & 2014 & 46.48 & 52.49 & 9.46 & 46.64 & 1.43 & 90.79 & 50.24 & 48.17 \\
\hline 79 & Nicaragua & 2008 & 53.72 & 63.14 & 35.68 & 56.50 & 39.11 & 55.74 & 52.42 & 51.57 \\
\hline 80 & Netherlands & 2009 & 95.28 & 88.51 & 84.91 & 90.53 & 92.90 & 93.23 & 91.35 & 93.78 \\
\hline 81 & Norway & 2006 & 81.16 & 70.67 & 79.65 & 83.91 & 91.99 & 88.88 & 82.87 & 85.24 \\
\hline 82 & Nepal & 2008 & 11.40 & 31.69 & 25.16 & 37.96 & 3.35 & 68.10 & 34.85 & 34.44 \\
\hline 83 & New_Zealand & 2013 & 72.83 & 85.72 & 78.84 & 89.57 & 50.42 & 80.03 & 77.41 & 78.48 \\
\hline 84 & Pakistan & 2014 & 33.87 & 45.27 & 19.22 & 48.01 & 32.32 & 87.30 & 51.02 & 48.64 \\
\hline 85 & Panama & 2006 & 91.07 & 65.78 & 50.23 & 73.96 & 47.74 & 56.13 & 64.69 & 65.63 \\
\hline 86 & Peru & 2006 & 66.78 & 67.15 & 32.70 & 54.46 & 37.01 & 84.09 & 62.39 & 62.50 \\
\hline 87 & Philippines & 2014 & 58.47 & 49.32 & 24.22 & 54.23 & 41.28 & 82.83 & 56.84 & 55.98 \\
\hline 88 & Poland & 2011 & 72.22 & 68.03 & 56.29 & 91.86 & 87.36 & 89.58 & 78.67 & 76.61 \\
\hline 89 & Portugal & 2013 & 79.89 & 82.09 & 68.63 & 91.19 & 89.70 & 88.98 & 84.05 & 83.54 \\
\hline 90 & Paraguay & 2008 & 53.18 & 57.92 & 36.26 & 60.83 & 37.09 & 75.13 & 57.14 & 56.32 \\
\hline 91 & Romania & 2006 & 60.44 & 60.73 & 44.18 & 78.72 & 38.69 & 89.91 & 66.50 & 64.99 \\
\hline 92 & Rwanda & 2006 & 19.54 & 34.11 & 23.81 & 38.03 & 4.27 & 60.31 & 34.49 & 34.22 \\
\hline 93 & Saudi_Arabia & 2006 & 52.82 & 76.19 & 70.24 & 69.12 & 82.06 & 57.24 & 65.22 & 66.57 \\
\hline 94 & Senegal & 2006 & 40.99 & 38.14 & 40.60 & 58.22 & 4.09 & 86.13 & 50.65 & 51.75 \\
\hline 95 & Singapore & 2014 & 99.01 & 96.53 & 93.20 & 85.75 & 96.53 & 54.77 & 83.64 & 87.04 \\
\hline 96 & Sierra_Leone & 2009 & 30.15 & 41.28 & 19.63 & 33.56 & 3.22 & 61.16 & 36.20 & 36.81 \\
\hline 97 & El_Salvador & 2011 & 57.17 & 63.11 & 35.53 & 66.64 & 41.19 & 78.63 & 60.89 & 59.25 \\
\hline 98 & Sweden & 2013 & 85.48 & 75.35 & 81.30 & 81.02 & 93.46 & 94.65 & 86.05 & 89.13 \\
\hline 99 & Swaziland & 2007 & 63.20 & 36.36 & 61.97 & 54.71 & 6.37 & 33.68 & 42.40 & 47.23 \\
\hline 100 & Syr_Arab_Rep & 2007 & 49.06 & 38.95 & 43.38 & 63.66 & 1.00 & 54.93 & 44.26 & 45.17 \\
\hline 101 & Chad & 2011 & 50.22 & 28.12 & 19.94 & 36.74 & 2.91 & 58.55 & 37.11 & 39.14 \\
\hline 102 & Togo & 2008 & 53.50 & 37.49 & 28.74 & 54.91 & 3.53 & 71.19 & 46.93 & 47.25 \\
\hline 103 & Thailand & 2008 & 74.06 & 55.41 & 39.67 & 68.67 & 37.94 & 78.48 & 62.87 & 62.95 \\
\hline 104 & Trinid \& Tobago & 2007 & 79.71 & 71.95 & 61.64 & 66.92 & 5.76 & 47.01 & 56.82 & 59.84 \\
\hline 105 & Tunisia & 2011 & 68.94 & 42.49 & 40.06 & 78.34 & 2.48 & 83.92 & 58.35 & 58.22 \\
\hline 106 & Turkey & 2006 & 46.77 & 69.54 & 40.93 & 72.69 & 78.12 & 89.96 & 69.07 & 65.92 \\
\hline 107 & Tanzania & 2006 & 27.06 & 50.59 & 17.16 & 33.54 & 2.61 & 55.17 & 35.78 & 34.91 \\
\hline 108 & Uganda & 2006 & 35.99 & 52.16 & 24.19 & 35.24 & 3.53 & 67.77 & 42.31 & 42.80 \\
\hline 109 & Uruguay & 2012 & 60.28 & 67.75 & 52.98 & 69.97 & 42.11 & 84.09 & 66.43 & 66.74 \\
\hline 110 & U.S.A. & 2009 & 59.05 & 78.48 & 66.91 & 81.46 & 91.77 & 91.43 & 79.14 & 78.47 \\
\hline 111 & Venezuela_RB & 2010 & 40.82 & 37.04 & 38.46 & 70.34 & 40.30 & 66.51 & 50.75 & 48.92 \\
\hline 112 & Vietnam & 2006 & 70.58 & 39.35 & 17.13 & 59.33 & 3.04 & 50.33 & 43.21 & 42.59 \\
\hline 113 & Yemen_Rep. & 2014 & 35.99 & 54.18 & 26.38 & 44.10 & 1.12 & 65.01 & 42.99 & 42.64 \\
\hline 114 & South_Africa & 2011 & 67.26 & 63.98 & 39.51 & 61.09 & 40.86 & 86.20 & 64.64 & 64.93 \\
\hline
\end{tabular}




\begin{tabular}{|c|c|c|c|c|c|c|c|c|c|c|}
\hline 115 & Congo_D_Rep. & 2006 & 19.87 & 28.69 & 8.76 & 34.02 & 1.00 & 44.96 & 26.11 & 24.95 \\
\hline 116 & Zambia & 2012 & 50.36 & 55.83 & 16.51 & 43.66 & 3.78 & 73.04 & 47.36 & 46.41 \\
\hline
\end{tabular}

E1, E2, S1, S2, S3, P and KOF are for the Year-L when the overall index AEMC attained minimum (Gmin) during 2006-2014. AEMC Indices are computed by the author.

Table-A-4. Economic, Social and Political Dimensions and Overall Indices of Globalization in Different Countries [Source: http://globalization.kof.ethz.ch]

\begin{tabular}{|c|c|c|c|c|c|c|c|c|c|c|c|}
\hline \multirow{2}{*}{$\begin{array}{l}\text { Endo- } \\
\text { genous }\end{array}$} & \multicolumn{9}{|c|}{ Exogenous / Predetermine Variables (Predictors at 2-SLS Stage-1) } & \multirow{2}{*}{$\begin{array}{l}\text { Con- } \\
\text { stant }\end{array}$} & \multirow{2}{*}{$\mathrm{R}^{2}$} \\
\hline & EPP06 & FOG06 & PPN06 & PCL06 & CVL06 & CP06 & HD06 & PCY06 & DI06 & & \\
\hline E1 & 0.0353 & -0.0880 & -0.0779 & -0.2510 & -0.3210 & 0.2066 & 0.7242 & 0.0561 & 0.4427 & 1.0808 & 0.5649 \\
\hline$(\mathrm{SEE})$ & 0.0351 & 0.0590 & 0.0706 & 0.1780 & 0.1642 & 0.1192 & 0.2361 & 0.0645 & 0.3166 & 0.8970 & \\
\hline $\mathrm{E} 2$ & 0.0093 & 0.0414 & -0.1017 & -0.1346 & -0.1563 & 0.1731 & 0.5338 & -0.0120 & 0.4174 & 0.9137 & 0.6268 \\
\hline SEE & 0.0263 & 0.0443 & 0.0529 & 0.1335 & 0.1231 & 0.0894 & 0.1771 & 0.0484 & 0.2374 & 0.6728 & \\
\hline $\mathrm{S} 1$ & 0.0538 & -0.0133 & 0.0376 & 0.2887 & 0.5016 & 0.3852 & 0.6971 & 0.1551 & -0.9627 & -0.9281 & 0.6954 \\
\hline (SEE) & 0.0440 & 0.0742 & 0.0887 & 0.2236 & 0.2063 & 0.1498 & 0.2967 & 0.0810 & 0.3978 & 1.1271 & \\
\hline $\mathrm{S} 2$ & 0.0039 & -0.0384 & 0.0397 & 0.0642 & 0.0830 & -0.0389 & 0.7784 & 0.0656 & -0.1078 & 0.5895 & 0.8359 \\
\hline (SEE) & 0.0171 & 0.0287 & 0.0343 & 0.0866 & 0.0799 & 0.0580 & 0.1149 & 0.0314 & 0.1540 & 0.4363 & \\
\hline S3 & 0.0452 & 0.0456 & -0.3037 & -0.8856 & -0.2577 & 0.0937 & 0.8872 & 0.7382 & 1.3123 & -4.0018 & 0.7214 \\
\hline (SEE) & 0.1046 & 0.1761 & 0.2107 & 0.5311 & 0.4899 & 0.3558 & 0.7047 & 0.1925 & 0.9447 & 2.6769 & \\
\hline $\mathrm{P}$ & -0.0140 & -0.0413 & 0.0590 & 0.1266 & 0.0154 & -0.1374 & -0.1605 & 0.0990 & 0.2297 & 3.5050 & 0.2545 \\
\hline (SEE) & 0.0317 & 0.0533 & 0.0638 & 0.1607 & 0.1483 & 0.1077 & 0.2133 & 0.0582 & 0.2859 & 0.8101 & \\
\hline DI16 & -0.0383 & 0.1010 & -0.0229 & 0.0314 & 0.2141 & 0.0861 & 0.0778 & -0.0198 & 0.5551 & 0.0727 & 0.8427 \\
\hline (SEE) & 0.0220 & 0.0370 & 0.0443 & 0.1117 & 0.1030 & 0.0748 & 0.1482 & 0.0405 & 0.1987 & 0.5630 & \\
\hline CP16 & 0.0026 & 0.0985 & -0.0403 & 0.0812 & 0.1666 & 0.6498 & -0.1923 & 0.0657 & -0.1688 & 1.3076 & 0.8135 \\
\hline$(\mathrm{SEE})$ & 0.0244 & 0.0410 & 0.0491 & 0.1237 & 0.1141 & 0.0829 & 0.1641 & 0.0448 & 0.2200 & 0.6233 & \\
\hline HD15 & 0.0025 & -0.0054 & -0.0162 & 0.0176 & -0.0085 & 0.0002 & 0.8315 & -0.0015 & 0.0510 & -1.6935 & 0.9822 \\
\hline (SEE) & 0.0044 & 0.0075 & 0.0090 & 0.0226 & 0.0208 & 0.0151 & 0.0300 & 0.0082 & 0.0402 & 0.1138 & \\
\hline GI10 & 0.0138 & -0.0258 & -0.0116 & -0.0043 & -0.0235 & 0.1206 & 0.3406 & 0.0936 & 0.0985 & 1.6204 & 0.8527 \\
\hline (SEE) & 0.0149 & 0.0251 & 0.0300 & 0.0756 & 0.0697 & 0.0507 & 0.1003 & 0.0274 & 0.1345 & 0.3810 & \\
\hline SP16 & -0.0103 & 0.0007 & -0.0031 & -0.0005 & 0.0125 & 0.0715 & 0.4939 & 0.0169 & 0.1301 & 1.2664 & 0.9420 \\
\hline$(\mathrm{SEE})$ & 0.0075 & 0.0127 & 0.0151 & 0.0382 & 0.0352 & 0.0256 & 0.0507 & 0.0138 & 0.0679 & 0.1924 & \\
\hline
\end{tabular}

Table-A-5. Coefficients of the Reduced Form Equation with their Standard Error of Estimate (SEE): Pessimistic Scenario 


\begin{tabular}{|c|c|c|c|c|c|c|c|c|c|c|c|}
\hline \multirow{2}{*}{$\begin{array}{l}\text { Endo- } \\
\text { genous }\end{array}$} & \multicolumn{9}{|c|}{ Exogenous / Predetermine Variables (Predictors at 2-SLS Stage-1) } & \multirow{2}{*}{$\begin{array}{l}\text { Con- } \\
\text { stant }\end{array}$} & \multirow{2}{*}{$\mathrm{R}^{2}$} \\
\hline & EPP06 & FOG06 & PPN06 & PCL06 & CVL06 & СР06 & HD06 & PCY06 & DI06 & & \\
\hline E1 & 0.0720 & -0.1249 & -0.0406 & -0.2353 & -0.3101 & 0.2985 & 0.4259 & 0.0228 & 0.2710 & 2.7392 & 0.4213 \\
\hline$(\mathrm{SEE})$ & 0.0317 & 0.0534 & 0.0639 & 0.1611 & 0.1486 & 0.1079 & 0.2138 & 0.0584 & 0.2866 & 0.8120 & \\
\hline E2 & 0.0055 & 0.0438 & -0.0611 & -0.1000 & -0.0985 & 0.1624 & 0.5962 & -0.0295 & 0.2559 & 0.9869 & 0.6512 \\
\hline SEE & 0.0231 & 0.0389 & 0.0466 & 0.1174 & 0.1083 & 0.0786 & 0.1557 & 0.0425 & 0.2088 & 0.5916 & \\
\hline $\mathrm{S} 1$ & 0.0331 & 0.0119 & -0.0114 & 0.2058 & 0.4477 & 0.2694 & 0.8125 & 0.1278 & -0.7073 & -1.1285 & 0.7051 \\
\hline (SEE) & 0.0407 & 0.0686 & 0.0821 & 0.2069 & 0.1908 & 0.1386 & 0.2745 & 0.0750 & 0.3680 & 1.0427 & \\
\hline $\mathrm{S} 2$ & 0.0051 & -0.0192 & 0.0634 & 0.0511 & 0.0611 & 0.0081 & 0.6361 & 0.0736 & -0.1898 & 1.3097 & 0.8366 \\
\hline (SEE) & 0.0154 & 0.0260 & 0.0311 & 0.0783 & 0.0723 & 0.0525 & 0.1040 & 0.0284 & 0.1394 & 0.3949 & \\
\hline S3 & 0.0601 & 0.0847 & -0.3366 & -1.0896 & -0.5415 & -0.1104 & 1.3049 & 0.7577 & 1.5880 & -4.1574 & 0.7269 \\
\hline (SEE) & 0.1062 & 0.1789 & 0.2139 & 0.5394 & 0.4975 & 0.3614 & 0.7157 & 0.1955 & 0.9594 & 2.7185 & \\
\hline $\mathrm{P}$ & 0.0164 & -0.0399 & 0.0444 & 0.1394 & -0.0656 & -0.0102 & -0.1109 & 0.0651 & 0.1193 & 3.7019 & 0.2994 \\
\hline (SEE) & 0.0231 & 0.0389 & 0.0465 & 0.1173 & 0.1082 & 0.0786 & 0.1556 & 0.0425 & 0.2086 & 0.5912 & \\
\hline DI16 & -0.0383 & 0.1010 & -0.0229 & 0.0314 & 0.2141 & 0.0861 & 0.0778 & -0.0198 & 0.5551 & 0.0727 & 0.8427 \\
\hline (SEE) & 0.0220 & 0.0370 & 0.0443 & 0.1117 & 0.1030 & 0.0748 & 0.1482 & 0.0405 & 0.1987 & 0.5630 & \\
\hline CP16 & 0.0026 & 0.0985 & -0.0403 & 0.0812 & 0.1666 & 0.6498 & -0.1923 & 0.0657 & -0.1688 & 1.3076 & 0.8135 \\
\hline (SEE) & 0.0244 & 0.0410 & 0.0491 & 0.1237 & 0.1141 & 0.0829 & 0.1641 & 0.0448 & 0.2200 & 0.6233 & \\
\hline HD15 & 0.0025 & -0.0054 & -0.0162 & 0.0176 & -0.0085 & 0.0002 & 0.8315 & -0.0015 & 0.0510 & -1.6935 & 0.9822 \\
\hline (SEE) & 0.0044 & 0.0075 & 0.0090 & 0.0226 & 0.0208 & 0.0151 & 0.0300 & 0.0082 & 0.0402 & 0.1138 & \\
\hline GI10 & 0.0332 & -0.0379 & -0.0074 & 0.0012 & -0.0758 & 0.1441 & 0.3184 & 0.0739 & 0.0590 & 2.1082 & 0.8716 \\
\hline (SEE) & 0.0118 & 0.0199 & 0.0238 & 0.0600 & 0.0553 & 0.0402 & 0.0796 & 0.0217 & 0.1066 & 0.3022 & \\
\hline SP16 & -0.0103 & 0.0007 & -0.0031 & -0.0005 & 0.0125 & 0.0715 & 0.4939 & 0.0169 & 0.1301 & 1.2664 & 0.9420 \\
\hline (SEE) & 0.0075 & 0.0127 & 0.0151 & 0.0382 & 0.0352 & 0.0256 & 0.0507 & 0.0138 & 0.0679 & 0.1924 & \\
\hline
\end{tabular}

Table-A-6. Coefficients of the Reduced Form Equation with their Standard Error of Estimate (SEE): Optimistic Scenario 


\begin{tabular}{llllllllllll} 
Variable & E1 & E2 & S1 & S2 & S3 & P & DI $_{16}$ & $\mathrm{CP}_{16}$ & $\mathrm{HD}_{15}$ & $\mathrm{GI}_{10}$ & $\mathrm{SP}_{16}$ \\
\hline
\end{tabular}

Panel-1: Observed Response Variable and Expected Response Variable (Conventional 2-SLS or C-2-SLS) or $r(y, \widehat{y})$

\begin{tabular}{cccccccccccc}
\hline E1 & $\mathbf{0 . 7 3 1}$ & 0.760 & 0.790 & 0.896 & 0.821 & 0.376 & 0.678 & 0.759 & 0.970 & 0.904 & 0.951 \\
\hline E2 & 0.701 & $\mathbf{0 . 7 9 2}$ & 0.754 & 0.853 & 0.811 & 0.403 & 0.790 & 0.788 & 0.944 & 0.889 & 0.952 \\
\hline S1 & 0.700 & 0.732 & $\mathbf{0 . 8 2 4}$ & 0.863 & 0.806 & 0.388 & 0.690 & 0.829 & 0.915 & 0.904 & 0.930 \\
\hline S2 & 0.712 & 0.740 & 0.782 & $\mathbf{0 . 9 1 3}$ & 0.807 & 0.396 & 0.676 & 0.708 & 0.982 & 0.893 & 0.950 \\
\hline S3 & 0.703 & 0.760 & 0.783 & 0.883 & $\mathbf{0 . 8 3 1}$ & 0.430 & 0.771 & 0.770 & 0.944 & 0.905 & 0.953 \\
\hline P & 0.590 & 0.707 & 0.706 & 0.805 & 0.791 & $\mathbf{0 . 4 5 1}$ & 0.807 & 0.724 & 0.859 & 0.830 & 0.887 \\
\hline DI16 & 0.551 & 0.708 & 0.628 & 0.693 & 0.712 & 0.463 & $\mathbf{0 . 8 8 4}$ & 0.759 & 0.761 & 0.780 & 0.836 \\
\hline CP16 & 0.601 & 0.698 & 0.769 & 0.723 & 0.729 & 0.377 & 0.756 & $\mathbf{0 . 8 9 3}$ & 0.771 & 0.831 & 0.843 \\
\hline HD15 & 0.724 & 0.737 & 0.782 & 0.914 & 0.801 & 0.389 & 0.653 & 0.700 & $\mathbf{0 . 9 8 3}$ & 0.893 & 0.946 \\
\hline GI10 & 0.713 & 0.764 & 0.809 & 0.886 & 0.831 & 0.422 & 0.740 & 0.814 & 0.948 & $\mathbf{0 . 9 2 1}$ & 0.958 \\
\hline SP16 & 0.709 & 0.778 & 0.787 & 0.894 & 0.820 & 0.417 & 0.767 & 0.780 & 0.973 & 0.908 & $\mathbf{0 . 9 7 0}$ \\
\hline
\end{tabular}

Panel-2: Observed Response Variable and Expected Response Variable (Shapley Value 2-SLS or SV-2-SLS) or $r(y, \breve{y})$

\begin{tabular}{cccccccccccc}
\hline E1 & $\mathbf{0 . 7 0 9}$ & 0.762 & 0.813 & 0.875 & 0.812 & 0.411 & 0.730 & 0.832 & 0.941 & 0.916 & 0.953 \\
\hline E2 & 0.695 & $\mathbf{0 . 7 6 6}$ & 0.783 & 0.879 & 0.822 & 0.446 & 0.794 & 0.786 & 0.943 & 0.908 & 0.957 \\
\hline S1 & 0.701 & 0.778 & $\mathbf{0 . 7 9 6}$ & 0.867 & 0.820 & 0.427 & 0.787 & 0.832 & 0.938 & 0.914 & 0.959 \\
\hline S2 & 0.695 & 0.774 & 0.783 & $\mathbf{0 . 8 8 2}$ & 0.819 & 0.441 & 0.795 & 0.793 & 0.954 & 0.909 & 0.965 \\
\hline S3 & 0.671 & 0.748 & 0.778 & 0.850 & $\mathbf{0 . 7 8 8}$ & 0.453 & 0.784 & 0.819 & 0.911 & 0.897 & 0.941 \\
\hline P & 0.733 & 0.763 & 0.805 & 0.895 & 0.837 & $\mathbf{0 . 4 0 4}$ & 0.703 & 0.779 & 0.960 & 0.919 & 0.953 \\
\hline DI16 & 0.692 & 0.765 & 0.780 & 0.876 & 0.831 & 0.456 & $\mathbf{0 . 7 9 8}$ & 0.784 & 0.938 & 0.909 & 0.954 \\
\hline CP16 & 0.721 & 0.766 & 0.809 & 0.894 & 0.835 & 0.420 & 0.739 & $\mathbf{0 . 7 9 4}$ & 0.957 & 0.922 & 0.959 \\
\hline HD15 & 0.738 & 0.757 & 0.792 & 0.902 & 0.832 & 0.397 & 0.682 & 0.740 & $\mathbf{0 . 9 7 0}$ & 0.911 & 0.949 \\
\hline GI10 & 0.702 & 0.771 & 0.802 & 0.871 & 0.824 & 0.431 & 0.779 & 0.832 & 0.935 & $\mathbf{0 . 9 1 7}$ & 0.958 \\
\hline SP16 & 0.698 & 0.771 & 0.803 & 0.872 & 0.828 & 0.431 & 0.784 & 0.830 & 0.936 & 0.916 & $\mathbf{0 . 9 5 8}$ \\
\hline
\end{tabular}

Panel-3: C-2-SLS based Expected Response Variable and SV-2-SLS,

Expected Response Variable or $r(\hat{y}, \breve{y})$

\begin{tabular}{cccccccccccc}
\hline E1 & $\mathbf{0 . 9 7 1}$ & 0.961 & 0.965 & 0.965 & 0.925 & 0.990 & 0.954 & 0.982 & 0.990 & 0.968 & 0.968 \\
\hline E2 & 0.963 & $\mathbf{0 . 9 6 8}$ & 0.983 & 0.978 & 0.945 & 0.964 & 0.966 & 0.968 & 0.956 & 0.974 & 0.974 \\
\hline S1 & 0.982 & 0.944 & $\mathbf{0 . 9 6 6}$ & 0.949 & 0.946 & 0.973 & 0.947 & 0.976 & 0.958 & 0.974 & 0.974 \\
\hline S2 & 0.957 & 0.960 & 0.948 & $\mathbf{0 . 9 6 6}$ & 0.929 & 0.977 & 0.957 & 0.976 & 0.984 & 0.953 & 0.955 \\
\hline S3 & 0.961 & 0.991 & 0.975 & 0.982 & $\mathbf{0 . 9 4 8}$ & 0.979 & 0.984 & 0.985 & 0.976 & 0.981 & 0.980 \\
\hline P & 0.889 & 0.925 & 0.911 & 0.933 & 0.904 & $\mathbf{0 . 8 9 5}$ & 0.944 & 0.909 & 0.881 & 0.916 & 0.929 \\
\hline DI16 & 0.846 & 0.891 & 0.896 & 0.896 & 0.909 & 0.812 & $\mathbf{0 . 9 0 3}$ & 0.843 & 0.788 & 0.887 & 0.886 \\
\hline CP16 & 0.922 & 0.880 & 0.927 & 0.885 & 0.907 & 0.870 & 0.878 & $\mathbf{0 . 8 9 0}$ & 0.829 & 0.923 & 0.923 \\
\hline HD15 & 0.955 & 0.956 & 0.944 & 0.960 & 0.925 & 0.977 & 0.951 & 0.974 & $\mathbf{0 . 9 8 7}$ & 0.948 & 0.947 \\
\hline GI10 & 0.994 & 0.984 & 0.992 & 0.988 & 0.975 & 0.993 & 0.986 & 0.996 & 0.982 & $\mathbf{0 . 9 9 6}$ & 0.996 \\
\hline SP16 & 0.982 & 0.986 & 0.989 & 0.994 & 0.967 & 0.983 & 0.983 & 0.990 & 0.979 & 0.987 & $\mathbf{0 . 9 8 8}$ \\
\hline
\end{tabular}

Note: $\mathrm{y}=$ Observed response variable; $\widehat{y}=$ Expected response variable (C-2-SLS);

$\breve{y}=$ Expected response variable (SV-2-SLS) 


\begin{tabular}{llllllllllll} 
Variable & $\mathrm{E} 1$ & $\mathrm{E} 2$ & $\mathrm{~S} 1$ & $\mathrm{~S} 2$ & $\mathrm{~S} 3$ & $\mathrm{P}$ & $\mathrm{DI}_{16}$ & $\mathrm{CP}_{16}$ & $\mathrm{HD}_{15}$ & $\mathrm{GI}_{10}$ & $\mathrm{SP}_{16}$ \\
\hline
\end{tabular}

Panel-1: Observed Response Variable and Expected Response Variable (Conventional 2-SLS or C-2-SLS) or $r(y, \widehat{y})$

\begin{tabular}{cccccccccccc}
\hline E1 & $\mathbf{0 . 5 7 9}$ & 0.748 & 0.797 & 0.867 & 0.784 & 0.392 & 0.613 & 0.783 & 0.913 & 0.888 & 0.907 \\
\hline E2 & 0.540 & $\mathbf{0 . 8 0 6}$ & 0.781 & 0.861 & 0.807 & 0.436 & 0.776 & 0.775 & 0.958 & 0.888 & 0.958 \\
\hline S1 & 0.555 & 0.767 & $\mathbf{0 . 8 3 1}$ & 0.878 & 0.813 & 0.440 & 0.716 & 0.812 & 0.942 & 0.912 & 0.949 \\
\hline S2 & 0.541 & 0.761 & 0.799 & $\mathbf{0 . 9 1 3}$ & 0.815 & 0.431 & 0.654 & 0.709 & 0.977 & 0.895 & 0.944 \\
\hline S3 & 0.575 & 0.776 & 0.794 & 0.894 & $\mathbf{0 . 8 2 7}$ & 0.452 & 0.716 & 0.732 & 0.962 & 0.910 & 0.947 \\
\hline P & 0.552 & 0.750 & 0.782 & 0.837 & 0.797 & $\mathbf{0 . 4 6 9}$ & 0.691 & 0.827 & 0.889 & 0.902 & 0.913 \\
\hline DI16 & 0.469 & 0.725 & 0.674 & 0.686 & 0.715 & 0.480 & $\mathbf{0 . 8 6 2}$ & 0.791 & 0.777 & 0.801 & 0.845 \\
\hline CP16 & 0.496 & 0.717 & 0.779 & 0.755 & 0.717 & 0.461 & 0.785 & $\mathbf{0 . 8 7 3}$ & 0.813 & 0.850 & 0.873 \\
\hline HD15 & 0.548 & 0.765 & 0.810 & 0.913 & 0.820 & 0.433 & 0.665 & 0.727 & $\mathbf{0 . 9 7 6}$ & 0.902 & 0.948 \\
\hline GI10 & 0.555 & 0.777 & 0.825 & 0.887 & 0.821 & 0.468 & 0.733 & 0.821 & 0.946 & $\mathbf{0 . 9 2 3}$ & 0.957 \\
\hline SP16 & 0.536 & 0.796 & 0.810 & 0.889 & 0.821 & 0.455 & 0.767 & 0.780 & 0.973 & 0.906 & $\mathbf{0 . 9 7 0}$ \\
\hline
\end{tabular}

Panel-2: Observed Response Variable and Expected Response Variable (Shapley Value 2-SLS or SV-2-SLS) or $r(y, \breve{y})$

\begin{tabular}{cccccccccccc}
\hline E1 & $\mathbf{0 . 5 4 7}$ & 0.776 & 0.822 & 0.876 & 0.800 & 0.469 & 0.732 & 0.836 & 0.938 & 0.917 & 0.952 \\
\hline E2 & 0.554 & $\mathbf{0 . 7 8 2}$ & 0.800 & 0.880 & 0.815 & 0.489 & 0.774 & 0.792 & 0.943 & 0.917 & 0.955 \\
\hline S1 & 0.556 & 0.790 & $\mathbf{0 . 8 0 9}$ & 0.864 & 0.814 & 0.482 & 0.787 & 0.828 & 0.935 & 0.919 & 0.956 \\
\hline S2 & 0.528 & 0.789 & 0.803 & $\mathbf{0 . 8 8 2}$ & 0.815 & 0.481 & 0.788 & 0.791 & 0.956 & 0.907 & 0.965 \\
\hline S3 & 0.538 & 0.762 & 0.793 & 0.856 & $\mathbf{0 . 7 7 4}$ & 0.504 & 0.756 & 0.822 & 0.916 & 0.908 & 0.940 \\
\hline P & 0.580 & 0.775 & 0.823 & 0.896 & 0.835 & $\mathbf{0 . 4 5 0}$ & 0.696 & 0.781 & 0.958 & 0.926 & 0.951 \\
\hline DI16 & 0.556 & 0.784 & 0.810 & 0.885 & 0.826 & 0.485 & $\mathbf{0 . 7 6 5}$ & 0.794 & 0.953 & 0.923 & 0.961 \\
\hline CP16 & 0.575 & 0.779 & 0.821 & 0.891 & 0.828 & 0.474 & 0.733 & $\mathbf{0 . 7 9 5}$ & 0.955 & 0.930 & 0.957 \\
\hline HD15 & 0.600 & 0.764 & 0.806 & 0.894 & 0.830 & 0.441 & 0.657 & 0.739 & $\mathbf{0 . 9 5 7}$ & 0.921 & 0.936 \\
\hline GI10 & 0.547 & 0.782 & 0.816 & 0.871 & 0.817 & 0.482 & 0.777 & 0.833 & 0.935 & $\mathbf{0 . 9 1 9}$ & 0.958 \\
\hline SP16 & 0.543 & 0.783 & 0.819 & 0.871 & 0.821 & 0.478 & 0.781 & 0.831 & 0.937 & 0.918 & $\mathbf{0 . 9 5 8}$ \\
\hline
\end{tabular}

Panel-3: C-2-SLS based Expected Response Variable and SV-2-SLS, based Expected Response Variable or $r(\hat{y}, \breve{y})$

\begin{tabular}{cccccccccccc}
\hline E1 & $\mathbf{0 . 9 4 5}$ & 0.929 & 0.933 & 0.916 & 0.900 & 0.964 & 0.930 & 0.949 & 0.960 & 0.940 & 0.936 \\
\hline E2 & 0.961 & $\mathbf{0 . 9 7 0}$ & 0.979 & 0.978 & 0.944 & 0.961 & 0.972 & 0.967 & 0.949 & 0.970 & 0.971 \\
\hline S1 & 0.985 & 0.960 & $\mathbf{0 . 9 7 4}$ & 0.966 & 0.953 & 0.985 & 0.973 & 0.982 & 0.966 & 0.983 & 0.983 \\
\hline S2 & 0.954 & 0.961 & 0.943 & $\mathbf{0 . 9 6 6}$ & 0.933 & 0.978 & 0.969 & 0.972 & 0.975 & 0.951 & 0.951 \\
\hline S3 & 0.949 & 0.984 & 0.967 & 0.973 & $\mathbf{0 . 9 3 7}$ & 0.983 & 0.982 & 0.984 & 0.987 & 0.965 & 0.964 \\
\hline P & 0.972 & 0.945 & 0.962 & 0.944 & 0.960 & $\mathbf{0 . 9 6 0}$ & 0.959 & 0.959 & 0.940 & 0.969 & 0.966 \\
\hline DI16 & 0.868 & 0.888 & 0.919 & 0.891 & 0.893 & 0.832 & $\mathbf{0 . 8 8 7}$ & 0.865 & 0.803 & 0.901 & 0.900 \\
\hline CP16 & 0.940 & 0.902 & 0.942 & 0.908 & 0.932 & 0.888 & 0.909 & $\mathbf{0 . 9 1 0}$ & 0.846 & 0.940 & 0.941 \\
\hline HD15 & 0.961 & 0.967 & 0.952 & 0.970 & 0.937 & 0.985 & 0.974 & 0.979 & $\mathbf{0 . 9 8 1}$ & 0.959 & 0.960 \\
\hline GI10 & 0.995 & 0.983 & 0.989 & 0.985 & 0.977 & 0.992 & 0.992 & 0.994 & 0.973 & $\mathbf{0 . 9 9 6}$ & 0.995 \\
\hline SP16 & 0.981 & 0.983 & 0.986 & 0.994 & 0.966 & 0.981 & 0.990 & 0.987 & 0.965 & 0.986 & $\mathbf{0 . 9 8 8}$ \\
\hline
\end{tabular}

Note: $\mathrm{y}=$ Observed response variable; $\hat{y}=$ Expected response variable (C-2-SLS); $\breve{y}=$ Expected response variable (SV-2-SLS)

Table-A-8. Correlation between Original, Expected (C-2-SLS) and (SV-2-SLS) for Optimistic Globalization Scenario 


\section{MODEL SIMULTANIH JEDNAČINA GLOBALIZACIJE, KORUPCIJE, DEMOKRATIJE, LJUDSKOG RAZVOJA I DRUŠTVENOG NAPRETKA}

\section{Rezime:}

Ova studija gradi model simultane jednačine koji uspostavlja međusobne veze između mera globalizacije, mera demokratije, ljudskog razvoja, indeksa percepcije korupcije i dohotka po glavi stanovnika, što zajednički utiče na društveni napredak. Model ima jedanaest jednačina u kojima su varijable odgovora i varijable prediktora logično-linearno povezane. Empirijski podaci korišćeni za procenu modela odnose se na period 2006-2016. godine za 116 zemalja raspoređenih na svim kontinentima. Model je procenjen na osnovu konvencionalnih dvostepenih kvadrata (2-SLS) i alternativno modifikovanih 2-SLS u kojem je u drugoj fazi korišćena Shapley-eva vrednost regresijea za poboljšanje štetnih efekata kolinearnosti između varijabli prediktora. Modifikovani 2-SLS nadmašuje konvencionalni 2-SLS. Studija utvrđuje da globalizacija pozitivno utiče na demokratiju, ljudski razvoj i društveni kapital. Globalizacija smanjuje korupciju dok integritet promoviše globalizaciju. Demokratija, društveni kapital, ljudski razvoj i globalizacija pozitivno utiču na društveni napredak. Takođe je utvrđeno da su prekogranična lična veza, kulturna blizina, demokratija i društveni kapital elastični u odnosu na svoje prediktore.

Ključne reči: globalizacija, demokratija, društveni napredak, model simultanih jednačina, Shapley-eva vrednost regresije. 